\title{
Working in family firms: less paid but more secure?* Evidence from French matched employer-employee data
}

\author{
Andrea Bassanini \\ (OECD, ERMES-University Paris II and IZA) \\ Eve Caroli \\ (University Paris Dauphine, LEDa-LEGOS, Paris School of Economics and IZA) \\ Antoine Rebérioux \\ (University Paris Ouest-EconomiX) \\ Thomas Breda \\ (ENS and Paris School of Economics)
}

Keywords: family firms, wages, job security, compensating wage differentials, linked employer-employee data

JEL codes: G34, J31, J33, J63, L26

\footnotetext{
* The views expressed here are those of the authors and cannot be attributed to the OECD or its member countries. We are grateful to Laurent Bach, Luc Behaghel, Vincent Bignon, Sandra Black, Raj Chetty, Vincenzo Galasso, Roberto Galbiati, Marco Leonardi, Barbara Petrongolo, Thomas Philippon, Andrea Prat, Muriel Roger, Alfonso Rosolia, Sebastien Roux, John Van Reenen, Thijs van Rens and audiences at the 2010 CAED, 2011 RES, CEF.UP/NIPE LEED and ESSLE conferences, and at seminars in Berlin (Humboldt), Florence (EUI), Lyon (GATE), Nantes, Paris (EconomiX, Dauphine-LEDa, ERMES and PSE) and Tilburg for useful comments and suggestions. All errors are, obviously, ours. We also thank David Sraer and David Thesmar for sharing their data with us. Remote access to DADS data through the CASD (Centre d'Accès Securisé à Distance) is gratefully acknowledged. The authors also acknowledge financial support from the French research agency (Agence Nationale de la Recherche) - Grant n ANR-08-JCJC-0067-01.
} 


\begin{abstract}
We study compensation packages in family and non-family firms. Using French matched employer-employee data, we first show that family firms pay on average lower wages. We find that part of this wage gap is due to low wage workers sorting into family firms and high wage workers sorting into non-family firms. However, we also find evidence that company wage policies differ according to ownership status, so that the same worker is paid differently under family and non-family firm ownership. We also find evidence that family firms are characterised by lower job insecurity, as measured by dismissal rates and by the subjective risk of dismissal perceived by workers. In addition, family firms appear to rely less on dismissals - and more on hiring reductions - than non-family firms when they downsize. We show that compensating wage differentials account for a substantial part of the inverse relationship between the family/non-family gaps in wages and job security.
\end{abstract}

\title{
Résumé
}

Nous étudions les formes de rémunération des salariés dans les entreprises familiales et non familiales. Pour ce faire, nous utilisons des données françaises appariées employeur/salarié et nous montrons que les entreprises familiales versent, en moyenne, des salaires plus faibles à leurs employés. Nous montrons qu'une partie de cet écart de salaire est due au fait que les travailleurs "à bas salaires" s'auto-sélectionnent dans les entreprises familiales alors que les salariés "à haut salaires" s'auto-sélectionnent dans les entreprises non familiales. Cependant, nous mettons aussi en évidence le fait que les politiques salariales diffèrent en fonction de la propriété de l'entreprise, de sorte qu'un même salarié est payé différemment dans une entreprise familiale et non familiale. Nous montrons aussi que les entreprises familiales sont caractérisées par une insécurité de l'emploi plus faible, qu'on la mesure en termes de taux de licenciement ou de risque de licenciement perçu par les salariés. De plus, les entreprises familiales ont moins recours aux licenciements - et plus aux réductions d'embauches lorsqu'elles sont amenées à contracter le niveau d'emploi. Nous montrons enfin que les différences compensatrices de salaire expliquent une part importante de la relation inverse existant entre les écarts de salaires et de sécurité de l'emploi entre entreprises familiales et non familiales. 


\section{Introduction}

Firm heterogeneity has attracted much interest in recent years. There is growing evidence that, even within narrowly-defined industries, firms are persistently heterogeneous in several respects, including productivity, employment dynamics and wages, and that this is partly explained by firm specific attributes (see e.g. Syverson, 2011, Davis et al., 2006, Abowd et al., 1999b). One key characteristic of the firm is corporate ownership, with the two most common types of ownership being family firms and firms with no dominant owner. The literature on family firms has traditionally focused on corporate performance, trying to assess whether family firms are efficient ${ }^{1}$ or whether they give rise to private benefits of control (see e.g. Bertrand and Schoar, 2006).

The consequences of firm ownership for employee compensation have been much less researched so far. The existing literature focuses almost exclusively on CEO and managerial pay, with most papers suggesting that top executives earn less in family firms than in non family ones - see Gomez-Mejia et al. (2003), Bach and Serrano-Velarde (2009) and Bandiera et al. (2010). In contrast, the pay level of non-managerial workers has been largely neglected. Moreover, employee compensation cannot be reduced simply to pay. It has been shown that workers are concerned by job insecurity - and, in particular, by the risk of job loss (see Valletta, 2000, Nickell et al., 2002 and Clark and Postel-Vinay, 2009) - and that they are ready to trade-off lower wages against less churning by their employer (Böckerman et al. 2011). The literature in finance suggests that families have longer time horizons than nonfamily shareholders so that they can more credibly commit to implicit contracts (Anderson and Reeb, 2003). As a consequence, family firms would have a comparative advantage at establishing long-term employment relations, thereby offering greater job security to their employees (Stavrou et al., 2006).

In this paper, we study compensation packages in family and non-family firms. We focus on wages and job security of both managerial and non-managerial workers. We find that family ownership is associated with lower wages and greater job security and that this partly reflects compensating wage differentials. Nevertheless, we also find evidence that the family/non-

\footnotetext{
${ }^{1}$ The empirical evidence on this point is far from being clear cut. Some papers find that family firms outperform widely-held firms (Anderson and Reeb, 2003; Villalonga and Amit, 2006; Sraer and Thesmar, 2007; Fahlentrach, 2009). In contrast, other studies provide evidence that family firms under-perform (Claessens et al, 2000; Morck et al, 2000; Cronqvist and Nilsson, 2003; Bloom and Van Reenen, 2007) in particular when control is passed on to the descendants (Perez-Gonzalez, 2006; Bennedsen et al, 2007; Villalonga and Amit, 2010).
} 
family wage gap is partly due to assortative matching, with high-ability workers sorting into high-paying non-family firms and low-ability workers ending up in family firms.

We build a unique dataset by matching individual and establishment-level data on firm ownership, company accounts, establishment characteristics, worker flows and employees' social security records including wages. Looking at evidence on family firms in France is interesting since they account for a large share of national employment. Our dataset contains a cross-section of about 2,000 establishments in 2004 - of which a vast majority are not listed on the stock market - and longitudinal information on a subset of establishments and workers. Using these data, we estimate Mincerian wage equations augmented by family ownership. Controlling for standard workers' characteristics and establishment observed and unobserved heterogeneity, we find that gross hourly wages are about $5 \%$ lower in family firms than in non-family companies. We find that part of this wage gap is due to differences in unobserved characteristics of workers across family and non-family firms. When a family firm becomes non-family owned, low-ability workers tend to leave, while leavers tend to be high-ability workers when the transition takes place in the opposite direction. We interpret this observation as evidence of assortative matching. However, we also find that company wage policies change when ownership changes, so that workers staying in the same firm enjoy on average a $3 \%$ pay increase when a family firm becomes non-family owned and suffer a similar pay drop when the ownership transition occurs the other way round.

These changes in pay are mirrored by changes in job security. Using quarterly data on hirings and separations, we first show that a switch from family to non-family ownership is associated with a substantial increase in the dismissal rate (and vice versa). We also investigate whether family firms rely less on dismissals than non-family firms when they downsize, and find that this is actually the case. This is crucial for incumbent workers: if employed in a family firm, they face a lower risk of job loss when the firm is hit by a negative shock and has to destroy jobs. When this occurs, family firms appear to reduce hirings more and increase dismissals less than non-family firms, in order to accommodate the required staffing changes. These results are confirmed by subjective data: the risk of dismissal perceived by workers is significantly lower in family firms than in non-family ones.

The fact that family firms offer lower wages and greater job security suggests that a compensating wage differential mechanism may be at play. We find that this is actually the case for workers who stay in the same establishment when firm ownership changes: half of the wage increase they benefit from when a family firm becomes non-family owned appears 
to be a compensation for the rise in the risk of dismissal associated with that ownership transition.

Our paper is one of the very few investigating non-managerial pay in family firms. The only other paper we are aware of is Sraer and Thesmar (2007). On a repeated cross-section of French listed firms over 1994-2000, they estimate firm-level wage equations. Controlling for the workforce's occupational structure, they find a wage penalty of about $4.5 \%$ in family firms run by heir CEOs as compared to widely-held companies. Our paper shows that a similar family/non-family wage gap is also found when including non-listed companies. This is a key point since non-listed firms typically represent a very large share of employment. Moreover it allows us to have greater over-time variation in ownership status in our sample: listed companies are often large holdings which rarely change ownership whereas non-listed firms include subsidiaries which may be sold by one holding to another one, leading to a larger amount of ownership changes between family and non-family holders. This allows us to improve on Sraer and Thesmar (2007) on a second dimension, namely the control for unobserved heterogeneity across establishments and workers. In such a way, we can distinguish between assortative matching and the direct effect of family ownership in determining the pay level of individual employees.

Our paper also contributes to a second strand of literature which focuses on job security in family firms. So far, most papers have tackled this issue only indirectly. Stavrou et al. (2006) and Block (2010) investigate the relationship between corporate ownership and downsizing. Both papers find that family ownership is associated with smaller employment reductions conditional to downsizing. The key problem in interpreting these results is that a given amount of job destruction can result from either voluntary quits or hiring reductions or dismissals, and that only dismissals affect job security of incumbent workers. Sraer and Thesmar (2007) study the covariation of firm employment changes and industry-level shocks. They find that employment growth at the firm level is less sensitive to industry-level shocks in family firms than in non-family ones. ${ }^{2}$ However, here again, the focus is on employment reduction rather than on dismissals. We improve on these papers by directly focusing on the risk of job loss for incumbent workers. As far as we know, our paper is the first one to show that family firms display lower rates of dismissals. Consistent with this evidence, we also find

\footnotetext{
${ }^{2}$ In addition, D'Aurizio and Romano (2011) show that employment adjustments following a business-cycle downturn are more concentrated in subsidiaries (with respect to headquarters) in family firms than in non-family ones.
} 
that workers in family firms perceive a lower risk of job loss. This set of results, we argue, provides direct evidence of greater job security in family firms.

Finally, as far as we know, our paper is also the first showing direct evidence suggesting that compensating wage differentials account for a substantial part of the inverse relationship between the family/non-family gaps in wages and job security.

The layout of the rest of the paper is as follows. Section 1 presents the empirical strategy. Section 2 describes the dataset and presents summary statistics. Section 3 reports results on the relationship between family ownership, wages and job security. Section 4 concludes.

\section{Empirical specification}

\subsection{Wage equations}

In the first part of this article, we estimate the relationship between family ownership and wages. In order to do so, we start from a standard wage equation (see Mincer, 1974), augmented with family ownership:

$$
\log w_{i j}=\gamma F_{j}+X_{i} \alpha+Z_{j} \beta+\varepsilon_{i j}
$$

where $w_{i j}$ is the gross hourly wage of worker $i$ employed in establishment $j$ estimated for the year 2004 - the year for which we have ownership data for most establishments $-F_{j}$ is a dummy variable equal to 1 if the firm to which the establishment belongs is family-owned and 0 otherwise, $X_{i}$ is a vector of individual characteristics including occupation, age and tenure. We also control for a set of establishment and firm-level characteristics $\left(Z_{j}\right)$ including, among others, a large set of industry and regional dummies. Finally, $\varepsilon_{i j}$ is an error term. $^{3}$

One issue with this simple cross-section model is that estimates may be flawed by unobserved heterogeneity across establishments. For a subset of establishments, we have ownership status in 1998 and 2004. In order to control for heterogeneity in unobservable time-invariant

\footnotetext{
${ }^{3}$ Our dataset is representative of the population of establishments in the French private sector. All individual regressions in this paper are therefore weighted by the inverse of the number of observations of each establishment, in order to give the same weight to each establishment. By avoiding that our results be driven by larger firms and plants, this also maintains comparability with establishment-level equations, such as those on separations (see below). In addition, as the source of variation of ownership status is at the level of firms, errors are assumed to be correlated within firms.
} 
characteristics, we re-estimate equation (1) on the pooled sample covering both available years, including a time dummy and establishment fixed effects. However, in this specification, the effect of $F$ is identified by transitions between ownership statuses, which is potentially endogenous because firms changing ownership status might be different from other firms and these differences might be correlated with wage changes. We do not have a valid instrument for the change in $F$. However if firms changing ownership were on average different from others, we would expect this to be reflected in some differences in pre-change characteristics (such as firm age as well as level and growth of profitability, productivity, wages or size). Therefore, in order to validate our identification strategy, we check that $\Delta F$ is uncorrelated with pre-change firm characteristics. ${ }^{4}$

A natural explanation of why wages may differ across family and non-family firms is that workers may be different in both types of companies. If, for any reason, workers with specific (unobservable) characteristics tend to match with family (resp. non-family) firms, the pattern of wages that we observe may be partly due to this assortative matching mechanism. In order to investigate this issue, we estimate the following equations:

$$
\begin{aligned}
& \log w_{i j, 1998}=X_{i, 1998} \alpha+\beta \text { Leaver }_{i j}+\delta \Delta F_{j} * \text { Leaver }_{i j}+\mu_{j}+\varepsilon_{i j} \\
& \log w_{i j, 2004}=X_{i, 2004} \alpha^{\prime}+\beta^{\prime} \text { Arriver }_{i j}+\delta^{\prime} \Delta F_{j} * \text { Arriver }_{i j}+\mu_{j}^{\prime}+\varepsilon_{i j}
\end{aligned}
$$

where $\Delta F_{j}$ is the change in ownership over the period (namely family ownership in 2004 minus family ownership in 1998) and $\mu_{j}$ and $\mu_{j}^{\prime}$ are establishment fixed effects. Leaver $_{\mathrm{ij}}$ is a dummy variable taking value 1 if the worker was in establishment $j$ in 1998 and was not there any longer in 2004, and 0 otherwise. Similarly, Arriver $_{\mathrm{ij}}$ is a dummy variable taking value 1 if the worker was not in establishment $j$ in 1998 but was there in 2004 and 0 otherwise. ${ }^{5}$ In this set-up, any estimate of $\delta$ and/or $\delta^{\prime}$ significantly different from 0 suggests that workers with specific unobservable characteristics correlated with the wage level leave (or join) family firms when they become non-family (or vice versa), hence providing an indication of assortative matching between workers and firms. More precisely, provided that the coefficient $\delta$ does not depend on the direction of the transition, $\delta>0$ indicates that the difference in 1998

\footnotetext{
${ }^{4}$ We also check that the coefficient of $F$ does not depend on the direction of the ownership transition (see Section 3 below).

${ }^{5}$ Let us underline that in the vast majority of cases we do not have information on the type of ownership (either family or non-family) of the firm the worker goes to when she leaves establishment $j$ or where she comes from when arriving at establishment $j$. This is due to the fact that those firms do not belong to the REPONSE dataset which provides us with the information on ownership - see Section 2.
} 
wage levels between leavers and stayers is greater in non-family firms becoming familyowned (and smaller in family-firms becoming non-family-owned) than in firms remaining in the same ownership status, which we use as a sort of control group. The same holds for $\delta^{\prime}$ as regards the difference in 2004 wage levels between arrivers and stayers.

Beside differences in the observed and unobserved characteristics of their workforce, a potential gap in wages between family and non-family firms may also occur because the same worker is paid differently in firms with different ownership statuses, to the extent that they do not apply the same wage policy. In order to estimate this effect, controlling also for timeinvariant unobserved heterogeneity across workers, we estimate the following long-difference equation on the sub-sample of workers who do not change establishment over the period:

$$
\Delta \log w_{i j}=\gamma \Delta F_{j}+\Delta X_{i} \alpha+\Delta Z_{j} \beta+u_{i j}
$$

where $\Delta \log w_{i j}$ denotes the change in the gross hourly wage of worker $i$ continuously employed in establishment $j$ between 1998 and 2004. $\Delta F_{j}$ is the change in ownership over the period, $\Delta X_{i}$ and $\Delta Z_{j}$ are two sets of time-varying individual and establishment controls, respectively, and $u$ is the error term. Of course, correctly estimating equation (4) requires taking into account the potential selection of workers into firms.

\subsection{Job security}

As a second step, we investigate whether family firms offer a specific compensation package including more job security. We first estimate the relationship between family ownership and different types of separation rates. In our data, separation rates are available for each quarter over 1997-2007 whereas family ownership, establishment and firm-level controls are available for most establishments only for the year $2004^{6}$. Some types of separations, including dismissals, fluctuate quite a lot over time and are 0 in a number of quarters. This is why we average them over a rather long period of time roughly corresponding to an entire cycle (2001-2007) centred on the year for which we have ownership status for most establishments. The model we estimate is then the following:

$$
S_{j}^{a}=\gamma F_{j}+Z_{j} \beta+\varepsilon_{j t}
$$

\footnotetext{
${ }^{6}$ And, for a subsample of establishments, for 1998.
} 
where $S_{j}^{a}$ is the average separation rate of type $a$ (dismissal, voluntary quit, retirement, end of trial period and end of fixed-term contract), in establishment $j$ over 2001-2007, $F_{j}$ is our dummy variable indicating family ownership and $Z_{j}$ is a vector of establishment and firmlevel controls. ${ }^{7}$ As we try to establish some statements concerning job security, our main interest is on dismissal rates. Nevertheless, it is important to look also at other types of separations in order to make sure that a lower level of one type of separation is not compensated by a higher level of another type.

Here again, our results could be driven by unobserved heterogeneity across establishments. In order to overcome this problem, we re-estimate equation (5) in long differences on the subsample of establishments for which we have ownership data both in 1998 and 2004. In order to do so in a meaningful way, we re-compute average separation rates over shorter periods (3 years) centred on years for which we have ownership status. In practice, we estimate:

$$
\Delta S_{j}^{a}=\gamma \Delta F_{j}+\Delta Z_{j} \beta+u_{j}
$$

where $\Delta S_{j}^{a}$ is the change in the separation rate of type $a$ in establishment $j$ between 19971999 and 2003-2005, $\Delta F_{j}$ is the change in ownership over the period and $\Delta Z_{j}$ denotes timevarying establishment controls.

A particularly important issue for the job security of incumbent workers is the behaviour of their employer when a negative shock forces her to destroy jobs. In such case, there is clearly a greater risk that the positions of incumbent workers be suppressed independently of the effort they pay in their job. So, we estimate whether, when family firms are hit by a negative shock and downsize, they rely more or less on dismissals than non-family firms do under the same circumstances. We do so by looking at the sensitivity of establishment-level dismissals to establishment-level job creation and destruction and testing whether this sensitivity differs between family and non-family firms. However, other establishment-level characteristics are likely to affect this sensitivity (notably establishment age) and we need to control for them in our estimates. Our model is the following:

$$
D R_{j t}=\alpha_{1 j} J C R_{j t}+\alpha_{2 j} J D R_{j t}+D_{t}+\mu_{j}+\varepsilon_{j t}
$$

\footnotetext{
${ }^{7}$ We also conduct robustness checks on a shorter time period around the year for which ownership information is available (2003-2005).
} 
where $D R_{j t}$ is the dismissal rate in establishment $j$ at quarter $t, J C R_{j t}\left(\right.$ resp. $\left.J D R_{j t}\right)$ is the job creation (resp. destruction) rate, $D_{\mathrm{t}}$ is a time dummy and $\mu_{j}$ is an establishment fixed effect, which allows us to take into account that dismissal rates are persistently different across establishments. ${ }^{8}$ The coefficients of $J C R_{j t}$ (resp. $J D R_{j t}$ ) are assumed to vary across establishments according to the following model:

$$
\begin{aligned}
& \alpha_{1 j}=\alpha_{1}+\gamma_{1} F_{j}+Z_{j} \beta_{1} \\
& \alpha_{2 j}=\alpha_{2}+\gamma_{2} F_{j}+Z_{j} \beta_{2}
\end{aligned}
$$

where $F_{j}$ and $Z_{j}$ are defined as for equation (5) and refer to 2004. Plugging equation (8) into equation (7) yields the final regression that we estimate:

$$
D R_{j t}=\alpha_{1} J C R_{j t}+\alpha_{2} J D R_{j t}+\gamma_{1} F_{j} J C R_{j t}+\gamma_{2} F_{j} J D R_{j t}+Z_{j} J C R_{j t} \beta_{1}+Z_{j} J D R_{j t} \beta_{2}+D_{t}+\mu_{j}+\varepsilon_{j t}
$$

A negative coefficient on the $J D R_{j t} F_{j}$ interaction term would suggest that family firms rely less on dismissals than non-family firms when they downsize. However, when firms are hit by a negative shock and have to downsize, the frontier between dismissals and quits may be somewhat blurred, insofar as firms may put pressure on workers so that they quit, either directly or by cutting their wage and worsening their working conditions. As a consequence, we also want to check that the estimated pattern for dismissals is not compensated by an opposite one for quits. In order to do so, we re-estimate the model of equation (9) using quits as a dependent variable. If family firms rely less on dismissals when hit by a negative shock, it must be the case that they make the necessary adjustment by compressing hiring. We check this by re-running our estimates with hiring as a dependent variable, as well.

Finally, another key aspect of job security as part of a compensation package is whether workers in family firms effectively feel that they have a smaller risk of losing their job. For the year 2004 and a subset of workers, we dispose of data on self-reported perceptions of the future risk of job loss. For those workers, we estimate the cross-sectional relationship between family ownership and the perceived risk of dismissal. The basic specification is equivalent to equation (1):

$$
R D_{i j}=\gamma F_{j}+X_{i} \alpha+Z_{j} \beta+\varepsilon_{i j}
$$

\footnotetext{
${ }^{8}$ Here again, we take a relatively large time window (2001-2007), centred on the year for which we have ownership status for most establishments (2004).
} 
where $R D_{i j}$ is the risk of dismissal perceived by worker $i$ employed in establishment $j$.

\section{The data}

The data we use come from several data sources as it is necessary to combine information on wages, firm ownership, worker flows, employees' characteristics, as well as a wide array of firms' and/or establishments' characteristics.

The first data source that we use is the 2004 wave of the REPONSE survey (RElations PrOfessionnelles et NégocationS d'Entreprise, which was also conducted in France in 1992 and 1998). To our knowledge, it is one of the very few databases that include information on ownership status of companies that are both listed and not listed on the stock market. In 2004, a representative sample of 2,930 establishments with at least 20 employees was surveyed. Questions about firm ownership, the use of information and communication technologies (ICT) and innovative managerial practices, as well as establishment characteristics were asked to one top manager per establishment. Regarding firm ownership, the manager is asked: "What is the type of the main category of shareholder of the firm?" According to the answer, we group firms into two main categories: those with family ownership (the main shareholder is either a family or an individual) and those with non-family ownership (i.e. for which ownership is either dispersed or private equity or which are joint-ventures). Other categories are charities, associations and governmental organisations operating in the business sector, as well as firms owned by their own workers, by the government or by other types of shareholders. We define a dummy variable which takes value 1 if the firm is owned by a family or an individual and 0 otherwise. We will call it "family ownership" or "family firm" hereafter. With this definition of family ownership, family firms account for $58.2 \%$ of the total number of firms in our sample. Our definition of family ownership is very close to that of Bloom and Van Reenen (2007) for whom a firm is family owned if the top manager who is interviewed reports that the largest shareholder is either the founder or family members who are second generation or beyond. Using this definition, they find a proportion of family firms in France of 56\%, out of which $26 \%$ are founder-owned and $30 \%$ are owned by second generation (or beyond) family members. Both Bloom and Van Reenen's and our sample include non-listed along with listed companies. By contrast, Sraer and Thesmar (2007), who only focus on a restricted sample of French listed firms, use a different definition of family ownership: a firm is family-owned if the family or a member has more than $20 \%$ of the voting 
rights. This definition of family firms on the basis of ultimate ownership is frequent in the literature on listed companies - see Faccio and Lang (2002). However, data on ultimate ownership are not available in a reliable form for non-listed companies whatever the country - see for example Bianco et al. (2009) for Italy. This is why we rely on the information on the main type of shareholder provided by the top manager interviewed in the REPONSE survey ${ }^{9}$.

To the extent that we are interested in contrasting compensation packages between family firms on the one hand and widely-held, private equity or joint-venture companies on the other hand, we exclude other types of firms from the sample, thus bringing our sample down to 2,133 establishments. ${ }^{10}$

REPONSE also provides information on the use of information and communication technologies (ICT) and innovative managerial practices. Managers are asked what proportion of the employees use computers, the Internet or the Intranet. For each of these new technologies, the answer is coded from 0 to 4 with 0 corresponding to "nobody", 1 to "less than 5\%", 2 to "5-19\%", 3 to "20 to 49\%" and 4 to "50\% and more". Our ICT variable is defined as the sum of the answers over the three types of technologies. It thus captures the intensity of use of ICT at the establishment level and varies between 0 and 12. We standardise it to 0 mean and 1 standard deviation. As regards innovative managerial practices, we build a summary index along the lines suggested by Bloom and Van Reenen (2007). In the REPONSE survey we have information on the proportion of workers involved in performance dialogue (expression groups, shopfloor meetings, quality circles), the number of devices designed to stimulate workers' participation (firm project, seminars, firm newspaper, open day, suggestion box, satisfaction survey), whether workers are autonomous in handling tasks and whether their work is defined in terms of goal to reach rather than in terms of precise actions. Managers are also asked the number of areas in which quantitative targets exist (financial return, budget, cost, quality, growth, security), whether there exist a training scheme, individual or collective wage incentive schemes (both for managers and nonmanagers), evaluations of individual workers and whether the assessment of employees' performance has any impact on wages or promotions. We build one variable out of the answer given for each item - see the Data Appendix for more details. Our summary index is then defined as the weighted sum of each of these variables so that they equally contribute to the

\footnotetext{
${ }^{9}$ Let us underline that, despite the difference in the definition of ownership and the period of analysis, out of the 65 firms which are common to Sraer and Thesmar's and our datasets, the answer about ownership is identical for 54 firms (i.e. $82 \%$ of the total).

${ }^{10}$ In this sample the proportion of establishments belonging to a family firm is $51 \%$ - see Appendix Table A1.
} 
overall index ${ }^{11}$. One interesting point is that family firms appear to be much less innovative than non-family ones both in terms of ICT and in terms of managerial practices (see Appendix Table A1).

Finally, the REPONSE dataset provides information on establishment size, age, the presence of a union representative in the establishment and whether or not it is (or it belongs to a group which is) listed on the stock market. As can be seen from Appendix Table A1, establishments in family firms are, on average, smaller than in non-family ones ${ }^{12}$, they are less likely to belong to a firm that is listed on the stock market and union representatives are much less frequent than in non-family firms.

Information on labour productivity (defined as valued added per worker at the firm level) comes from the DIANE database which contains publicly-available company accounts ${ }^{13}$. As shown in Table A1, labour productivity is substantially lower in family firms as compared to non-family ones. We also draw from DIANE information on profitability and firm age.

The REPONSE and DIANE datasets have been matched with Social Security records (Déclarations Annuelles de Données Sociales, DADS). These contain information on gross hourly wages (constructed as gross annual wages divided by the number of hours worked), gender, age, occupation, working full time or part-time, and a rough measure of job tenure ${ }^{14}$ for nearly all workers in the French private sector. Matching the DADS files with REPONSE and DIANE leaves us with 511,230 employees working in 1,995 establishments of whom $35 \%$ are employed in family-owned establishments and $65 \%$ in non-family establishments. Such a design generates linked employer-employee information, which allows us to study individual compensation taking into account both firm and worker heterogeneity on observable characteristics. As usually done with the DADS and to eliminate implausible values of hourly wages due to misreporting of either annual wages or hours worked, we drop the lowest and highest percentile of the hourly wage distribution ${ }^{15}$. We also exclude CEOs and top executives. As evidenced in Appendix Table A2, in 2004, family establishments paid on average lower wages, employed more women and fewer highly-skilled workers (managers and technicians) than non-family establishments. In contrast, average age and tenure as well

\footnotetext{
${ }^{11}$ Here again, we standardise the index to 0 mean and 1 standard deviation.

${ }^{12}$ Let us underline that despite this difference in average size between family and non very firms, the size distributions of both groups overlap to a very large extent.

${ }^{13}$ It is provided by Bureau van Dijk, a private consulting company, and it is the French source file for the more famous Amadeus database.

${ }^{14}$ We know whether workers have tenure less than one year, between one and two years, or more than two years.

${ }^{15}$ See Abowd et al (1999b). Our results are nonetheless robust to the inclusion of these extreme hourly wages.
} 
as part-time work were very similar in both types of firms. Information about individual workers is also provided by the REPONSE survey. In 2004, for each establishment, on average 4 workers answered a written questionnaire. They were randomly drawn out of the group of workers with more than 15 months of tenure. They were asked questions about their job, and in particular the risk they perceive of losing it in the next 12 months. Using this information, we build a variable capturing the perceived risk of dismissal which takes values 1 to 4 when the risk is perceived as being respectively "zero", "low", "high" and "very high".

The REPONSE survey has a panel subsample which provides information on establishments in 1998 and 2004 by means of the manager questionnaire. It contains 481 establishments for which we have data on family ownership at both dates. We match it with the DADS panel for which we have yearly data from 1994 to 2006. This panel covers $1 / 12^{\text {th }}$ of all workers in 2004 and $1 / 24^{\text {th }}$ in 1998 and enables us to follow workers from one year to the next. In $1998,4,713$ workers from the DADS panel are employed in one of the REPONSE establishments. About $2 / 3$ rds of these workers still were in the same establishment in 2004 whereas $1 / 3^{\text {rd }}$ had left usually to establishments outside the REPONSE panel. The information available in the DADS panel is similar to the DADS cross section except for job tenure which is more detailed (so that we are able to code it into 8 categories instead of 3 ). Changes in family ownership are captured through a variable defined as family ownership in 2004 minus family ownership in 1998. This variable may thus take values 0 (no change in ownership), +1 (family-owned in 2004 while it was not in 1998) and -1 (family-owned in 1998 while not anymore in 2004). On average, it is equal to 0.017 in our sample. But the proportion of firms changing ownership whatever the direction is much higher: $17 \%$ over the period, with about half of the changes taking place in each direction - see Appendix Table A3 for more descriptive statistics on changes in individual and establishment characteristics.

The last source that we use is the DMMO/ EMMO database. In principle, the DMMO (Données sur les Mouvements de Main-d'Oeuvre) has exhaustive quarterly data on gross worker flows (hirings and separations, excluding temporary help workers) for establishments with 50 employees or more. The data is broken down by type of flow. The EMMO (Enquête sur les Mouvements de Main-d'Oeuvre) has identical information on a representative sample of establishments with less than 50 employees. We match the DMMO and EMMO datasets with REPONSE 2004 and we are left with 1,803 establishments reporting information both on job and worker flows and on ownership. We use the DMMO-EMMO data to compute indicators of job security and, more specifically, of hiring and separation rates at the 
establishment level. In order to do that, we drop all movements corresponding to job spells shorter than one month. These indeed correspond to very short trial periods or short-term contracts which have little to do with job security for core workers ${ }^{16}$. We also exclude movements due to transfers between two establishments of the same firm. Our data allows us to build hiring and separation rates for each quarter over 2001-2007. ${ }^{17}$ As standard in the gross worker flow literature (Davis et al, 2006), the hiring rate is defined as the ratio of all hires during a given quarter to the average employment level of that quarter ${ }^{18}$ and the separation rate as the sum of all types of separations ${ }^{19}$ divided by average employment. In order to go deeper into the types of separations, we define dismissal rates, quit rates, retirement rates, rates of end of trial periods and rates of end of fixed-term contracts as the ratio of the corresponding type of movement during the quarter to the average employment of the quarter. Following the gross job flow literature (Davis et al., 1997), we also define the job creation rate as the net growth rate of employment in the establishment between the beginning and the end of the quarter when it is positive and 0 otherwise. Symmetrically, the job destruction rate is the absolute value of the net growth rate of employment when it is negative, and 0 otherwise. Appendix Table A4 presents descriptive statistics of worker and job flows.

\section{Results}

\subsection{Wages in family firms}

\subsubsection{Family firms pay lower wages}

Estimates from cross-sectional individual wage equations suggest that average gross hourly wages are lower in family than in non-family firms (see Table 1). The simple bivariate correlation between family ownership and wages - see column (1) - indicates that wages are about $20 \%$ lower in family firms than in non family ones. Not surprisingly, the family wage penalty is much smaller when we include standard establishment controls - establishment size and age, presence of a union representative, being listed on the stock market, 10 regional and

\footnotetext{
${ }^{16}$ Our results are nonetheless robust to the inclusion of these very short job spells.

17 2001-2007 is our main sample. We also have data going back to 1997, which allows us to construct quarterly separation rates for two other sub-periods: 1997-1999 and 2003-2005 on which we estimate our long difference specification - see Section 1 .

18 The average employment level of the quarter is defined as half of the sum of the employment levels at the beginning and the end of the quarter (see e.g. Davis et al., 2006).

${ }^{19}$ In the original data, separations are classified as due to dismissals, quits, retirement and early retirement, end of trial periods, end of fixed-term contracts, military service, injuries, death or separations for unknown reason.
} 
2-digit industry dummies - and workforce characteristics (i.e. occupation, gender, age, job tenure and part-time/full-time status). Nonetheless, when including all these controls, the wage gap between family and non-family firms still amounts to about $4 \%$, and is significant at the $1 \%$ level - see column (2). This suggests that this wage gap cannot be entirely explained by the fact that family businesses are overrepresented in specific industries, employ a larger share of unskilled workers and are less unionised - see Sraer and Thesmar (2007), Mueller and Philippon (2011) and our descriptive statistics in Appendix Table A1. Interestingly, all our results also hold if we exclude all managers from the sample, suggesting that the wage gap we detect is not limited to managerial occupations - see Appendix Table A5.

One could be concerned that these results might be driven by the fact that family firms employ family members who benefit from non-wage earnings and are, in turn, paid lower wages. If this were the case, our results would be driven by small establishments, since family members are unlikely to represent a large fraction of the workforce in large firms. In order to check that our results are robust to the elimination of smaller establishments, we re-run our regressions on establishments with more than 50 workers. Our findings are virtually unchanged, thus suggesting that earnings of family members do not account for a major part of the family/non-family wage gap that we find.

Bloom and Van Reenen (2007) find that family firms are less innovative - and hence less productive - than non-family ones. We find similar evidence in our data using indicators constructed in the same way as theirs (see Section 2). ${ }^{20}$ When controlling for intensity of ICT use and innovative managerial practices in the wage regression, the coefficient on family firms decreases to $2.4 \%$ but remains significant at the $1 \%$ level (Table 1, Column 3). Not surprisingly, similar results hold if we control directly for firm-level labour productivity (Table 1, Column 4). ${ }^{21}$

Results in Table 1 could also be driven by other sources of heterogeneity across firms that we are unable to observe directly. In Table 2 we use the REPONSE and DADS panels to investigate this issue and re-estimate our wage equation on the subsample of establishments (and employees), for which we have ownership data in both 1998 and 2004. We include

20 Even controlling for workforce characteristics and standard establishment controls, family-owned establishments have on average lower indicators of ICT use and innovative managerial practices than establishments whose ownership is mainly widely held, private equity or joint ventures. As a consequence family firms are less productive, - see the longer version of this paper (Bassanini et al, 2011).

${ }^{21}$ The comparison of Columns 3 and 4 suggests that controlling for ICT and managerial practices is equivalent to control for firm-level productivity, consistent with the fact that the productivity gap between family and nonfamily firms disappears once ICT and managerial practices are included. In the remainder of the paper we show results controlling for the latter indicators but all results are qualitatively similar if we control for productivity. 
establishment fixed effects to control for time-invariant unobserved heterogeneity. The results from this exercise point to a larger wage gap than in the simple cross-section without fixed effects (Table 2, Column 1). When family firms change to non-family ownership (i.e. the family firm indicator shifts from 1 to 0 ), our results show that their average wages grow by $4.9 \%$ and this pay increase is significant at the $1 \%$ level. Moreover, this result does not appear to be due to specificities of the pooled sample that we use. If we re-estimate our baseline equation on this sample without fixed effects, we find a wage gap quite close to that found in the larger cross-sectional sample for 2004 (see Table A6 in the Appendix). ${ }^{22}$

As our results are identified through changes in family ownership, we might ask whether the direction of the transition matters: are changes from family to non-family ownership associated with an increase in wages as large as the decrease in wages observed when a nonfamily firm is sold to a family? We can investigate this issue by including an interaction between the family firm indicator and a time-invariant dummy that takes value 1 in both years if the firm was family-owned in 1998 and 0 otherwise. The coefficient of this interaction term turns out to be close to 0 and insignificant (Table 2, Column 2), suggesting that the effect of changes in family ownership is symmetric. ${ }^{23}$

Perhaps more important, we also worry that changes in family ownership may be endogenous, which can be problematic because we do not dispose of a suitable instrument. In particular, we expect specific shocks and/or different stages in the firm's lifecycle to be correlated with the probability of changing main shareholder. We worry that some unobserved factors associated to these shocks or lifecycle stages might determine the correlation between changes in family ownership and changes in wages that we observe in Table 2. However, in order to bias our results, these unobserved factors should affect differently changes in ownership status depending on the direction of the transition (from family to non-family and vice versa). If this were to occur, we would expect that a number of key firm characteristics,

\footnotetext{
${ }^{22}$ This suggests that there are unobserved establishment-level characteristics that are positively correlated with family ownership and wages. One possible candidate is the fact that family firms are able to more credibly commit to long-term relationships, which facilitates investments in match-specific capital. In turn, higher matchspecific capital is partially reflected in wages. Insofar as this capital takes time to build and is not immediately destroyed when a change of ownership status occurs, it can be considered to be approximately time-invariant in our pooled sample. Consistent with this hypothesis, we find that wage-tenure profiles are more upward-sloped in family than in non-family firms: if we estimate equation (1) separately on the samples of family and non-family firms, controlling for the full set of other covariates considered in Table 1, in family firms employees with job tenure greater than 20 years earn on average $16 \%$ more than those with less than one year as compared to only $7 \%$ more in non-family firms.

${ }^{23}$ This interaction term takes the same values in 1998 and 2004 except when the firm was non-family owned in 2004 and family owned in 1998. Once added to the specification, its coefficient thus identifies the difference between the effect of changes from non-family to family-ownership and that of changes from family to nonfamily ownership.
} 
which are likely to be correlated with these shocks or stages in the firm's life cycle (such as firm age and pre-change levels and growth of profitability, productivity, size, and wages), should differ systematically according to the direction of the transition and therefore be correlated with changes in family ownership. ${ }^{24}$ We do not find any such evidence (see Table A7 in the Appendix). ${ }^{25,26}$ Although we need to be very cautious in interpreting our results, this finding is reassuring and suggests that the timing of specific shocks, by affecting in the same way transitions from family to non-family firms and vice versa, is unlikely to bias the coefficient of the family firm indicator in Table 2.

Overall, our results suggest that changes in family ownership generate changes in average wages of about $5 \%$ and that this effect is symmetric whatever the direction of the change. At this point, an important question is whether this change in average wages is due to the fact that workers in family and non-family firms have different unobservable characteristics, or whether it is due to a change in the firm wage policy such that the same workers are paid in a different way in family and non-family firms.

\subsubsection{Assortative matching vs changes in stayers' wages}

A natural explanation of the change in average wages following a change in family ownership - that we find in Table 2 - is that workers are different in family and non-family firms. Although the specification in Table 2 controls for observable workers' characteristics, workers may differ with respect to unobservables. Given that non-family firms tend to be more innovative and more productive than family firms, they may attract more dynamic workers. If this is the case, part of the wage difference estimated in Table 2 may be due to an assortative

\footnotetext{
${ }^{24}$ We make here the assumption that unobserved factors affecting ownership changes are reflected in some key observable characteristics of the firm. Although debatable, this assumption is typically made in difference-indifference estimations when balancing tests between treatment and comparison groups are used to validate the identification strategy (see for example the discussion in Altonji et al., 2005).

${ }^{25}$ We obtain similar results to those presented in Table A7 if we restrict the sample by excluding firms not changing ownership.

${ }^{26}$ By contrast, as expected, we find that firms changing main shareholder (whatever its type) between 1998 and 2004 differ from other firms on a number of characteristics. More precisely, we do not dispose of information on all changes of main shareholder but we can construct a variable that takes value 1 every time the main shareholder changes type (in practice, change in main-shareholder type is equal to the absolute value of change in family ownership). Correlating this variable with several firm and establishment characteristics, we find that firms changing main shareholder type between 1998 and 2004 were on average significantly younger than other firms (results available from the authors upon request). In addition, they also had on average $18 \%$ greater employment growth in 1994-1998. However, insofar as in our sample there are an almost equal number of transitions from family to non-family ownership and vice versa, changes in main-shareholder type and changes in family ownership are uncorrelated. Therefore, establishing that firms changing main-shareholder type have specific characteristics has no implication for the correlation between changes in the family ownership indicator and these firm characteristics.
} 
matching mechanism rather than to the "true" impact of a change in wage policy brought about by the change in family ownership.

In order to investigate this issue we estimate whether workers who left a firm that changed family ownership between 1998 and 2004 had different wages from stayers' before the change took place (i.e. in 1998) - see equation (2). Symmetrically, we also estimate whether workers who arrive in a firm that changed ownership have different wage levels as of 2004 as compared to workers who have been continuously employed in the establishment between 1998 and 2004 - see equation (3). Results in Table 3 col (1) suggest that leavers are actually different from stayers: when a firm changes from non-family to family ownership ( $\Delta$ Family firm = 1), the difference in 1998 wages between workers who leave the firm and those who eventually stay turn out to be, on average, $6.5 \%$ higher than in firms not changing ownership. Similarly, the opposite occurs when a firm changes ownership from family to non-family. This result supports the idea that workers in non-family firms (resp. family firms) are "highwage" (resp. "low-wage") individuals - after controlling for observable characteristics - and that assortative matching is taking place, with a number of these workers leaving the firm when it switches from non-family to family (resp. from family to non-family) ownership. ${ }^{27}$ In contrast, we do not find any evidence of selection on arrivers: as shown in Table 3 col (2), the wage difference between arrivers and stayers is virtually identical whether firms change family ownership or not. This result is consistent with assortative matching to the extent that once poorly matched workers have left following the change in ownership, stayers are presumably properly matched and hence have no reason to be different from newly hired workers who have been chosen because they match the firm's needs (and/or characteristics).

So, part of the variation in wages we observe when firms change family ownership is due to a change in the unobservable composition of their workforce. However, a $6.5 \%$ wage difference over a population of leavers who represents about $1 / 3^{\text {rd }}$ of the total workforce (see Section 2) cannot fully account for the overall $5 \%$ wage change that we estimate when firms change family ownership. This suggests that some of the workers - those who tend to remain in the firm after a change in ownership - are likely to be paid differently in family and non-family firms because of different firm wage policies.

\footnotetext{
${ }^{27}$ We check that if the coefficients of the interaction between Leaver and $\Delta$ Family firm are allowed to depend on the direction of the ownership transition, their difference is statistically insignificant, so that we can claim that the sorting patterns are effectively symmetric.
} 
In order to quantify this effect, we estimate the impact of changes in family ownership on wage growth for workers who have been continuously employed in the same establishment between 1998 and 2004 - see equation (4). According to the results in Table 4 - Column 1, workers who stay in the same establishment when firm ownership changes do experience a change in their wage: when firms switch from non-family to family ownership ( $\Delta$ Family firm $=1$ ), stayers' wages go down by about $3.2 \%$ and vice versa when family ownership changes in the opposite direction. Yet, given the existence of assortative matching of workers and firms, one could be worried that our sample of stayers is selected at least on some dimensions, which would generate biases in the estimation of equation (4). However, while workers leaving firms that change family ownership differ from stayers because of some specific unobserved characteristics correlated with their wage level in 1998 (see Table 3), they have no different wage growth either before (1994-1998) or after the ownership change (20042006) ${ }^{28}$ - see Table A8, Columns 1 and 2, in the Appendix. ${ }^{29}$ This suggests that the observed sorting of workers into family and non-family firms is essentially driven by differences in unobserved characteristics that are likely to be time-invariant (such as individual productive ability) and, therefore, will be differenced out when estimating equation (4). In other words, we do not expect our estimates in Table 4 - Column 1 - to be significantly biased because of sample selection. However, we check that this is actually the case by running a couple of robustness checks.

Given that selection of workers into firms seems to be only driven by unobserved characteristics correlated with 1998 wage levels, we use a proxy-variable approach to further check that selectivity is not driving our results. More specifically, we proxy these unobservables by the relative wage of the individual in 1998 defined as the individual wage divided by the average wage in her establishment computed on all individuals, will they be stayers or leavers in the next period. ${ }^{30}$ Including this variable in the regression leaves our results unchanged - see Table 4, Column 2 - thereby supporting the idea that selectivity is not a major concern in our estimates. ${ }^{31}$

\footnotetext{
${ }^{28} 1994$ is the first year and 2006 is the last year for which we have access to comparable wage data.

${ }^{29}$ Specifications estimated in Table A8 - cols (1) and (2) - are based on equation (2) except that the dependent variables and the individual controls are differences over 1994-1998 and 2004-2006.

${ }^{30}$ This procedure appears to be justified by the fact that stayers and leavers do not appear to differ with respect to other characteristics in 1998 (such as age, gender, occupation, job tenure and full-time/part-time status - see Table A8, Columns (3) to (7), which suggests that the selection pattern is essentially determined by unobservables that are closely associated to the wage level (such as individual ability).

${ }^{31}$ An alternative way to deal with the issue of selectivity is the following. Given that "high-wage" workers leave non-family firms when they become family-owned and that "low-wage" workers do so when the change in
} 
To the extent that only $17 \%$ of firms change ownership in our sample between 1998 and 2004 , one could be concerned that the absence of conditional correlation that we find between relative wages in 1998 and subsequent wage growth might be driven by firms that did not change family ownership. In order to control for this, we re-run our estimates on the subsample of establishments that did change family ownership over the period. Results in Table 4 - Columns 3 and 4 - suggest that this is not a concern: the estimates are virtually identical to those computed on the whole sample.

Overall, family firms appear to pay lower wages. Part of the wage gap is due to differences in unobserved characteristics of workers across family and non-family firms. But part of it is also due to different wage policies being implemented by these firms, so that the same worker's pay is different in family and non-family companies, at least for those who tend to stay in the firm after a change in ownership. The finding that ownership type is associated with differences in wage policies raises the issue of whether it may also affect other components of the compensation package. Job security is one of the most important ones.

\subsection{Job security in family firms}

In this section we investigate whether family firms offer greater job security than their nonfamily counterparts. If so, this would point to a different compensation package offered by family firms characterised by lower wages but greater job security.

\subsubsection{Average separation rates}

A first way to look at job security in family firms is to consider separation rates and, more specifically, rates of dismissals which capture the risk of job loss for permanent workers. We use 2001-2007 averages to avoid that our results be affected by a large number of zeros in the case of certain separations (notably dismissals - see Section 2). Results in Table 5 - Column 1 - show that dismissal rates are significantly lower in family firms even after controlling for our basic set of establishment and worker controls, including ICT and managerial practices

\footnotetext{
ownership goes in the opposite direction, one may try to identify a sort of "common support". By excluding the top and bottom deciles of the relative wage distribution (dated 1998), we define a "restricted" sample of workers. We check that, on this sample, there is no evidence of selection - that is, that the $\delta$ parameter in equation (2) is not significantly different from zero. We then re-estimate equation (4) on this restricted subsample. Results provided in Table A9 show that the coefficient on the $\Delta$ Family Firm variable is not statistically different from the one we find in Table 4. Here again, this suggests that selectivity is unlikely to be a major issue in our results.
} 
and industry dummies. ${ }^{32}$ The difference in dismissal rates between family and non-family firms is estimated to be as large as 0.15 percentage point per quarter, which amounts to a $28 \%$ gap between both types of firms (cf. Table A4). This suggests that the risk of involuntary job loss is substantially lower in family than in non-family firms. One interesting point is that the low level of dismissals is not compensated for by other types of separations - see Columns 2 to 5: family firms do not display higher levels of quits, retirement, end of trial periods or end of fixed-term contracts.

However, specifications in Table 5 do not control for the proportion of permanent workers in the establishment. This may be a problem since external flexibility in family firms might be ensured by fixed-term contracts. As involuntary separations at the end of a fixed-term contract are not reported as dismissals in the data ${ }^{33}$ this may create a bias in our estimates. In principle, given the small share of workers on fixed-term contracts in our sample, this should not be a major problem. ${ }^{34}$ Nevertheless, in order to deal with this problem, Appendix Table A10 Column 1 - re-estimates the dismissal equation controlling for the proportion of permanent workers in the establishment in 2004, drawn from the REPONSE dataset. ${ }^{35}$ The results are very similar to those in Table 5. Family firms still display lower rates of dismissals. Given that our information on firm ownership is for 2004, a further robustness check consists in reducing our sample to dismissals taking place in 2003-2005, i.e. a short period of time centred around the date for which we have information on ownership. Family firms still display lower dismissal rates - see Table A10, Column 2.

Of course, time-invariant unobserved heterogeneity across establishments could be driving our results. In order to deal with this issue, we re-estimate our model in long differences between 1998 and 2004 - see Table 6. The results are very similar to those in Table 5 with changes from non-family to family ownership $(\Delta F=1)$ inducing a reduction in the rate of dismissals. Let us underline that this result is unlikely to be driven by changes in the unobserved composition of the workforce. As evidenced in section 3.1.2, in the case of a transition from non-family to family ownership, workers who stay in the establishment have worse productive abilities than those who left. To the extent that these workers have greater propensity to be dismissed, this is likely to bias our estimates towards zero, if anything.

\footnotetext{
32 The DMMO-EMMO files do not report these firm characteristics, which are therefore drawn from the REPONSE survey and thus refer to 2004.

${ }^{33}$ They are simply classified as separations due to end of contract.

${ }^{34}$ Workers on fixed-term contracts amount, on average, to $5 \%$ of the workforce in our sample.

${ }^{35}$ Information on the share of workers on fixed-term contracts is neither available in the DMMO-EMMO nor in the DADS datasets. As a consequence, we do not dispose of a time series for this share.
} 
Finally, as discussed when estimating our wage equation including establishment fixed effects, we do not find any evidence of unobserved factors affecting differently ownership changes depending on the direction of the transition (from family to non-family and vice versa). Observable characteristics of firms are indeed uncorrelated with $\Delta$ Family Firm - see Table A7 - so that we believe it is unlikely that selectivity be a major driver of our estimates.

\subsubsection{Downsizing through dismissals or hiring reductions?}

As a second step, we investigate whether family firms rely less on dismissals than non-family firms do when they downsize. This is indeed a crucial issue for incumbent workers: when a firm downsizes, they have a greater chance to lose their job independently of their effort. Do they face a lower risk of job loss when the firm is hit by a negative shock, if employed in a family firm? In order to shed light on this point, we regress dismissal rates on job creation and job destruction rates as well as their interaction with family ownership - see equation (9). As evidenced in Table 7 - Panel A, job destruction rates are strongly correlated with dismissals, even controlling for establishment heterogeneity in separations through establishment fixedeffects - see Column $1 .{ }^{36}$ When comparing adjustment patterns in family and non family firms - see Column 2 - family firms appear to rely less than non-family ones on dismissals when employment contracts: the coefficient on the interaction between family ownership and the job destruction rate is negative and significant. A consistent finding emerges when we use the hiring rate as dependent variable. Column 2 in Panel B of Table 7 shows a negative and significant coefficient on the interaction between family ownership and the job destruction rate even in this case. As a consequence, when facing a negative shock, family firms tend to achieve the required staff adjustment by reducing hiring more and by increasing dismissals less than non-family firms do.

One concern about these results is that establishments with different size, age etc., operating in different sectors or with different workers' characteristics could react in a different way to job creation or job destruction which could be confounded with the effect of family ownership. In order to control for this, Columns 3 and 4 of Table 7 - Panels A and B progressively include interaction terms between job creation and job destruction on the one

\footnotetext{
${ }^{36}$ As regards the adjustment to job creation, the positive coefficient on the JCR variable in Table 7 might suggest that dismissals increase with employment expansion - although this effect is substantially smaller for family firms as indicated by the negative coefficients on the interaction between family ownership and job creation. This is consistent with previous evidence for France (see Abowd et al, 1999a). It is probably due to the fact that, when expanding, non-family firms make a lot of experimentation with new recruits which generates many hiring and separations of workers that stay with the firm only for a short period of time (see Jovanovic, 1979, and Pries and Rogerson, 2005).
} 
hand and these potentially confounding factors on the other hand. Our main result is robust to these changes: family firms consistently appear to rely less on dismissals and to compress hiring more when hit by a negative shock.

\subsubsection{Subjective data on job security}

The fact that family firms offer greater job security is confirmed by subjective data. In Table 8, we use the information, available in the employee section of the 2004 REPONSE survey, on the risk perceived by workers of loosing their job in the next 12 months ${ }^{37}$. More specifically, we regress the perceived risk of dismissal on family ownership using a specification identical to the one elicited for wages. As evidenced in Column 1, workers in family firms perceive a lower risk of dismissal even after controlling for establishment and worker characteristics. In order to better control for unobserved heterogeneity across workers, Column 2 adds the individual wage to the previous specification. The results are virtually unchanged: the risk of dismissal perceived by workers remains lower in family firms.

Overall, our results suggest that family firms do provide more job security to incumbent workers: not only do they have lower average dismissal rates but, when employment goes down, they also reduce hiring more than non-family firms do and consistently, they rely less on dismissals. Workers are aware of this difference in firms' behaviour, with those employed in family firms reporting significantly lower perceived risk of dismissal.

\subsection{Compensating wage differential}

Our results on stayers' wages, on the one hand, and job security, on the other hand, raise the issue of a possible compensation between pay and job security. If workers who stay in an establishment which changes from non-family to family ownership experience a reduction in wages, to what extent can this change in pay be explained by a compensating wage differential mechanism, whereby workers would accept lower wages in exchange for greater job security? Similarly, in the event of a transition from family to non-family ownership, to what extent does the wage increase act as a compensation for reduced job security?

In order to provide evidence on this point, one would estimate:

$$
\Delta \log w_{i j}=\gamma \Delta F_{j}+\delta \Delta D_{j}+\Delta X_{i} \alpha+\Delta Z_{j} \beta+u_{i j}
$$

\footnotetext{
${ }^{37}$ This perceived risk may be "very high", "high", "low" or "zero". From these responses, we construct an indicator which varies between 1 and 4 that we treat as a cardinal variable. Nevertheless, we also estimate ordered probit models where this variable is treated as ordinal only with similar results.
} 
in which the variables are the same as in equation (4) with $\Delta D_{j}$ denoting the change in the rate of dismissal in establishment $j$ between 1998 and 2004. In this set-up, the prediction associated with compensating wage differential is that $\hat{\delta}$ should be positive and $\hat{\gamma}$ should go down to zero - with $\wedge$ indicating estimates. Any increase in the rate of dismissal should indeed be matched by a corresponding increase in log wages. In addition, if changes in stayers' wages are entirely due to changes in dismissals brought about by changes in family ownership, the coefficient on $\Delta F$ should be found close to zero when estimating equation (11).

One problem is that $\Delta D$ is endogenous and OLS estimates of $\delta$ are likely to be biased downwards. This is because any negative shock affecting the establishment is likely to induce at the same time an increase in dismissals and a reduction in wages. As a matter of fact, when estimating equation (11) on our whole sample, the coefficient on $\Delta D$ turns out to be insignificant and very close to zero - see Table 9, Column 1 - while that on $\Delta F$ remains unchanged. Now, suppose that the firm wage policy changes only when there is a change in family ownership. Then, insofar as $83 \%$ of the establishments in our sample do not change family ownership between 1998 and 2004, the estimate of the coefficient of $\Delta D$ would be essentially driven by firms not changing wage policy. As a consequence, it would mainly be determined by the correlation of changes in wages and changes in dismissals with adverse shocks, which would explain its negative sign. Consistent with this interpretation, when we re-estimate the specification on the subsample of establishments that did not change ownership between 1998 and 2004 - Table 9, Column 2 - we still obtain a negative estimate for the coefficient of $\Delta D$. By contrast, when estimating equation (11) on the subsample of establishments that did change family ownership, we find some evidence of compensating wage differential. In this case, the effects of potential shocks affecting the establishments are dominated by the change in wage and job-security policy brought about by the change in family ownership. An increase in dismissals is then positively associated with a positive change in log wages (at the 10\% significance level) and the magnitude of the coefficient on $\Delta$ Family Firm is reduced by $44 \%$ - from -0.34 in Table 4, Column 3, to -0.19 in Table 9, Column 3 - and is no longer significant at conventional levels. We interpret this result as suggesting that part of the change in wages experienced by stayers when family ownership changes is due to a compensating wage differential mechanism: following a transition from non-family to family ownership wages tend to go down, but in exchange workers benefit from 
greater job security. Similarly if a family firm becomes non-family owned, wages go up for stayers partly as a compensation of reduced job security.

\section{Discussion}

In this paper, we provide evidence that French family firms offer a specific compensation package to their employees involving lower wages but greater job security. Controlling for individual characteristics and establishment fixed effects, we find that family firms pay their employees about $5 \%$ less than non-family firms. This result is identified by changes in family ownership. Given that we do not have an instrument for changes in ownership, one needs to be cautious in interpreting our findings. However, the lack of correlation between the change in family ownership and pre-change firm characteristics and outcomes suggests that our estimates are unlikely to be seriously flawed by the endogeneity of the timing of ownership changes.

Part of the family/non-family wage gap that we find appears to be due to differences in unobserved characteristics of workers across family and non-family firms. But part of it is also due to different wage policies being implemented by both categories of firms, so that the same worker's pay is different in family and non-family companies. Ceteris paribus, family firms also feature a substantially lower dismissal rate than non-family firms, which is robust to controlling for establishment fixed effects. Moreover, when hit by a negative shock that induces employment downsizing, family firms appear to rely less on dismissals and more on hiring contraction than non-family firms in order to achieve the required staff adjustment. These results are confirmed by information on the workers' perception of the risk of dismissal: workers in family firms feel that their job is more secure, even conditional on their wage level. The fact that family firms offer lower wages and greater job security suggests that some compensating wage differential mechanism may be at play. We find evidence of such compensation for workers who stay in the same establishment when firm ownership changes: we estimate that about half of the decrease in their wage is accounted for by a lower risk of dismissal when ownership changes from non-family to family ownership (and vice versa when ownership changes the other way round).

What explains the difference between family and non-family firms in terms of compensation packages? The agency theory provides a first explanation. It indeed states that executive compensation is designed to align the interests of managers with those of shareholders 
(Murphy, 1999). As underlined by Jensen and Meckling (1976) the risk of misalignment is larger for firms with dispersed ownership because it is more difficult for shareholders to control managers' actions. In contrast, managers have less discretion as to the actions they take when there are large blockholders. So, in equilibrium, managers' compensation (including wages, premiums and bonuses) should be more performance-related and therefore on average higher in non-family firms, where control is looser. This extends to nonmanagerial workers as soon as intrinsinc motivations, such as aversion to within-firm inequality, are taken into account (see Rebitzer and Taylor, 2011). This may also explain greater job insecurity in non-family firms if firms with dispersed ownership use the threat of dismissal under bad performances as a tool to create more powerful incentives.

An alternative theory consistent with our findings is provided by the literature in finance. This suggests that family firms may have a comparative advantage at credibly committing to longterm relationships, including long-lasting job matches. The main reason for this is that families have long-term horizons ${ }^{38}$ and are therefore more prone to investment opportunities that are profitable only in the long-run (see e.g. Anderson and Reeb, 2003, Bertrand and Schoar, 2006). As a consequence, family firms may have a comparative advantage at offering job security and may therefore afford to pay lower wages. In addition, our results suggest that they might have a comparative disadvantage at innovation, in particular as regards the use of ICT and innovative managerial practices. This would turn into a comparative advantage of non-family firms at offering attractive pay schemes and hence higher wages in compensation for lower job security - on which they cannot credibly commit.

Whatever the theory elicited to explain our findings, they seem consistent with a multiple equilibrium model, in which family firms are in a low-pay/high-job-security equilibrium, while non-family firms are in a high-pay/low-job-security one. Changing ownership is then equivalent to moving from one equilibrium to the other. Why do some workers go away and others stay in the same establishment when this occurs? Those who stay are presumably workers with high moving costs. Once these moving costs are taken into account, they are

\footnotetext{
${ }^{38}$ The idea that family firms have longer time horizon might seem at odd with the fact that in our data, changes from family to non-family ownership are as frequent as changes from non-family to family ownership. Let us underline though that this does not imply that family firms change main shareholder as frequently as non-family firms. Firms may indeed change main shareholder either because they switch from family to non-family ownership (or the other way round) or they may change main shareholder while remaining family owned or nonfamily owned. The REPONSE survey also has direct information on all changes in main shareholder for the period 2002-2004. In our sample only $8 \%$ of family firms changed main shareholder over this period as compared to $19 \%$ for non-family firms. This suggests that family firms change ownership much less frequently than non-family firms which is consistent with the idea that they have a longer time horizon.
} 
indifferent between both types of equilibrium to the extent that they are compensated: by higher wages in exchange for lower job security when ownership changes from family to nonfamily and by greater job security in exchange for lower pay when the transition takes place the other way round.

Other workers leave their establishment when ownership changes. One potential explanation for this might be the existence of a complementarity between ICT and innovative managerial practices on the one hand and high ability on the other. In this case, high-ability workers would leave firms when they become family-owned because family firms would not compensate them properly for the large decrease in wages they would have to suffer if staying, due to the sharp reduction in the intensity of ICT and innovative managerial practices. Symmetrically, low-ability workers would leave family firms when they become non-family either because they get fired or because they are offered wage levels which do not compensate them for the lower degree of job security. However, our data do not quite support this interpretation. When controlling for changes in ICT and managerial practices interacted with Leaver in equation (2), the coefficients on both interaction terms are insignificant and the point estimate and standard error on $\Delta F^{*}$ Leaver remain unchanged. This suggests that the assortative matching we observe between high (resp. low) ability workers and non-family (resp. family) firms is not driven by their different intensity of use of ICT and innovative managerial practices.

An alternative explanation would then be that workers who leave their establishment when ownership changes have different preferences in terms of wages and/or job security. Highability workers would leave non-family firms when they become family-owned because they have a relative preference for wages over job security, whereas the opposite holds for lowability workers leaving family firms when they become non-family owned. Some very preliminary indication of this can be found in our data. In the worker section of the REPONSE survey, individuals are asked what pushes them to put a lot of themselves into their job. "Wage incentives" and "promotion prospects" are among the possible choices and for each of them workers may answer "yes, a lot", "yes, to some extent", "not really", "not at all". For each item, we group answers into two categories: "yes" and "no". Regressing the wage incentive and promotion prospect indicators on our dummy variable for family ownership and the usual set of individual and establishment-level controls, we find that workers in family firms are significantly less sensitive to wage incentives and to career 
prospects than workers in non-family firms. ${ }^{39}$ This is consistent with assortative matching taking place on the basis of preferences as evidenced, for top managers, by Bandiera et al. (2010). Our data do not allow us to go further along these lines. However, investigating potential differences in preferences across workers employed in family vs. non-family firms appears to be a promising avenue for future research.

\section{References}

Abowd John, Patrick Corbel and Francis Kramarz, 1999a, "The Entry and Exit of Workers and the Growth of Employment: An Analysis of French Establishments", The Review of Economics and Statistics, 81(2), pp. 170-87.

Abowd John, Francis Kramarz and David Margolis, 1999b, "High-Wage Workers and HighWage Firms", Econometrica, 67(2), pp. 251-333.

Altonji Joseph, Todd Elder and Christopher Taber, 2005, "Selection on Observed and Unobserved Variables: Assessing the Effectiveness of Catholic Schools", Journal of Political Economy, 113(1), pp. 151-84.

Anderson Ronald and David Reeb, 2003, "Founding-Family Ownership and Firm Performance: Evidence from the S\&P 500", The Journal of Finance, 58(3), pp. 1301-28.

Bach Laurent and Nicolas Serrano-Velarde, 2009, "The Power of Dynastic Commitment", Oxford University Centre for Business Taxation Working Paper ${ }^{\circ}$ 09-24.

Bandiera Oriana, Luigi Guiso, Andrea Prat and Rafaella Sadun, 2010, "Matching Firms, Managers and Incentives", Harvard Business School Strategy Unit Working Paper n ${ }^{\circ} 10-073$.

Bassanini Andrea, Eve Caroli, Antoine Reberioux and Thomas Breda, 2011, "Working in family firms: less paid but more secure? Evidence from French matched employer-employee data", IZA Working Paper, n5842.

Bennedsen Morten, Kasper Meisner Nielsen, Francisco Perez-Gonzalez and Daniel Wolfenzon, 2007, "Inside the Family Firm: the Role of Families in Succession Decisions and Performance", The Quarterly Journal of Economics, 122(2), pp. 647-91.

Bertrand Marianne and Antoinette Schoar, 2006, "The Role of Family in Family firms", Journal of Economic Perspectives, 20(2), pp. 73-96.

Bianco Magda, Roberto Golinelli and Giuseppe Parigi, 2009, "Family Firms and Investments", ECGI - Finance Working Paper n 269/2009.

Block Joern Hendrich, 2010, "Family Management, Family Ownership and Downsizing: Evidence from S\&P 500 Firms", Family Business Review, 23, pp.109-130.

Bloom Nicholas and John Van Reenen, 2007, "Measuring and Explaining Management Practices across Firms and Countries", The Quarterly Journal of Economics, 122(4), pp. 1351-1408.

\footnotetext{
${ }^{39}$ The corresponding point estimates and standard errors are $-0.52(0.018)$ for wage incentives and $-0.42(0.017)$ for career prospects. The results are qualitatively similar if controlling for the worker's wage and her exposure to a wage incentive scheme.
} 
Böckerman, Petri, Pekka Ilmakunnas and Edvard Johansson, 2011, "Job Security and Employee Well-Being: Evidence from Matched Survey and Register Data", Labour Economics, 18(4), pp. 547-54.

Clark Andrew and Fabien Postel-Vinay, 2009, "Job Security and Job Protection", Oxford Economic Papers, 61(2), pp. 207-39.

Claessens Stijn, Simeon Djankov and Larry Lang, 2000, "The Separation of Ownership and Control in East Asian Corporations", Journal of Financial Economics, 58(1-2), pp. 81-112.

Cronqvist Henrik and Mattias Nilsson, 2003, "Agency Costs of Controlling Minority ShareHolders", Journal of Financial and Quantitative Analysis, 38(4), pp. 695-719.

D'Aurizio Leandro and Livio Romano, 2011, "Family firms and the Great Recession: Out of Sight, Out of Mind?", mimeo EUI, Florence.

Davis Steven, Jason Faberman and John Haltiwanger, 2006 "The Flow Approach to Labor Markets: New Data Sources and Micro-Macro Links", Journal of Economic Perspectives, 20(3), pp. 3-26.

Davis Steven, John Haltiwanger and Scott Schuh, 1997, Job Creation and Destruction, Cambridge (Mass): the MIT Press.

Faccio, Mara and Larry Lang, 2002, "The Ultimate Ownership of Western European Corporations", Journal of Financial Economics, 65, pp. 365-395.

Fahlenbrach, Rüdiger, 2009, "Founder-CEOs, Investment Decisions and Stock Market Performance", Journal of Financial and Quantitative Analysis, 44(2), pp. 439-66.

Gomez-Mejia Luis, Martin Larraza-Kintana and Marianna Makri, 2003, "The Determinants of Executive Compensastion in Family-Controlled Public Corporations", Academy of Management Journal, 46(2), pp. 226-37.

Jensen Michael and William Meckling, 1976, "Theory of the Firm: Managerial Behavior, Agency Costs and Ownership Structure", Journal of Financial Economics, 3(4), pp. 305-60.

Jovanovic Boyan, 1979, "Job Matching and the Theory of Turnover", Journal of Political Economy, 87(5), pp. 972-90.

Mincer Jacob, 1974, Schooling, Experience and Earnings, New-York: Columbia University Press.

Morck Randall, David Stangeland and Bernard Yeung, 2000, "Inherited Wealth, Corporate Control, and Economic Growth: The Canadian Disease?" in Randall Morck ed, Concentrated Corporate Ownership, NBER Conference Volume, Chicago: University of Chicago Press.

Mueller Holger and Thomas Philippon, 2011, "Family firms and Labor Relations", American Economic Journal: Macroeconomics, 3(2), pp. 218-245.

Murphy Kevin, 1999, "Executive Compensation", in Orley Ashenfelter and David Card editors, Handbook of Labor Economics, Volume 3B, Chapter 38, pp. 2485-2557.

Nickell Stephen, Patricia Jones and Glenda Quintini, 2002, "A Picture of Job Insecurity facing British Men", The Economic Journal, 112(January), pp. 1-27.

Perez-Gonzalez Francisco, 2006, "Inherited Control and Firm Performance", The American Economic Review, 96(5), pp. 1559-88.

Pries Michael and Richard Rogerson, 2005, "Hiring Policies, Labor Market Institutions and Labor Market Flows", Journal of Political Economy, 113(4), pp. 811-39. 
Rebitzer James and Taylor Lowell, 2011, "Extrinsic Rewards and Intrinsic Motives: Standard and Behavioral Approaches to Agency and Labor Market", in David Card and Orley Ashenfelter eds, Handbook of Labor Economics, 4A, Amsterdam: North-Holland, pp. 701-72.

Sraer David and David Thesmar, 2007, "Performance and Behavior of Family Firms: Evidence from the French Stock Market", Journal of the European Economic Association, 5(4), pp. 709-51.

Stavrou Eleni, George Kassinis and Alexis Filotheou, 2006, "Downsizing and Stakeholder Orientation among the Fortune 500: Does Family Ownership Matter?", Journal of Business Ethics, 72(2), pp. 149-62.

Syverson Chad, 2011, "What Determines Productivity?", Journal of Economic Literature, 49(2), 326-365.

Valletta Robert, 2000, "Declining Job Security", in David Neumark ed., On the Job: is LongTerm Employment a Thing of the Past?, New-York: Russell Sage, pp. 227-56.

Villalonga, Belen and Raphael Amit, 2006, "How do Family Ownership, Control and Management Affect Firm Value?", Journal of Financial Economics, 80(2), pp. 385-417.

Villalonga, Belen and Raphael Amit, 2010, "Family Control of Firms and Industries", Financial Management, 39(3), pp. 863-904. 


\section{Tables}

Table 1 Family firms and wages in 2004

(1) (2) (3) (4)

\begin{tabular}{lcccc} 
Dependent variable & Log Wage & Log Wage & Log Wage & Log Wage \\
\hline Family firm & $-0.198^{* * *}$ & $-0.042^{* * *}$ & $-0.024 * * *$ & $-0.029 * * *$ \\
& $(0.012)$ & $(0.008)$ & $(0.008)$ & $(0.007)$ \\
Observations & 511,230 & 502,452 & 417,071 & 402,862 \\
R-squared & 0.064 & 0.631 & 0.626 & 0.638 \\
Workers' controls & no & yes & yes & yes \\
Establishments' controls & no & yes & yes & yes \\
Controls for ICT and Manag. Pract. & no & no & yes & no \\
Control for log productivity & no & no & no & yes \\
\hline
\end{tabular}

Notes: (1) Dependent variable: $\log$ gross hourly wage. Family firm takes value 1 if the establishment is part of a firm which is family-owned and 0 otherwise. (2) Robust standard errors, clustered on firms, in parentheses. (3) Workers' controls include: age (8 classes), tenure (3 classes), occupation (4 groups: manager, technician or supervisor, clerk, blue-collar), gender and a dummy variable for working full time. (4) Establishment controls include: establishment size (6 classes), age (5 classes), region, presence of union representative, being listed on the stock market and industry dummies (at 2-digits of the NACE, Rev.1, classification). (5) ICT and Management Practices are the intensity of use of information and communication technologies and of innovative managerial practices, respectively. Log productivity is the $\log$ of value added per worker. (6) $* * * \mathrm{p}<0.01, * * \mathrm{p}<0.05, * \mathrm{p}<0.1$.

Table 2 Family firms, ICT, management practices and wages Establishment fixed effects, 1998-2004.

\begin{tabular}{lcc}
\hline \hline & $(1)$ & $(2)$ \\
Dependent variable & Log Wage & Log Wage \\
\hline & $-0.049^{* * *}$ & $-0.047 * * *$ \\
Family firm & $(0.014)$ & $(0.015)$ \\
& & -0.004 \\
Family firm*Family firm in 1998 & & $(0.032)$ \\
& & 8,812 \\
Observations & 8,812 & 0.784 \\
R-squared & 0.784 & yes \\
Workers' controls & yes & yes \\
Controls for ICT and Management Pract. & yes & yes \\
Other time-varying establishment controls & yes & yes \\
Time dummy & yes & yes \\
Establishment fixed-effects & yes & .
\end{tabular}

Notes: (1) Dependent variable: log gross hourly wage. Family firm takes value 1 if the establishment is part of a firm which is family-owned and 0 otherwise. Family firm in 1998 takes value 1 if the establishment was part of a firm which is family-owned in 1998. (2) Robust standard errors, clustered on firms by years, in parentheses. (3) ICT and Management Practices are the intensity of use of information and communication technologies and of innovative managerial practices, respectively. All regressions include two dummy variables that take the value 1 if ICT (resp. management practices) is missing (4) Workers' controls include: age (8 classes), tenure (8 classes), occupation (4 groups: manager, technician or supervisor, clerk, blue-collar), gender and a dummy variable for working full time. (5) Other time-varying establishment controls include: establishment size (6 classes), presence of union representative and being listed on the stock market. (6) *** $\mathrm{p}<0.01, * * \mathrm{p}<0.05,{ }^{*} \mathrm{p}<0.1$. 
Table 3. Change in family ownership and wages of leavers, arrivers and stayers.

(1)

Dependent variable

Log Wage

1998

0.014

Leaver

$(0.011)$

$0.065 * * *$

Leaver* $\Delta$ Family firm

$(0.022)$

Arriver

Arriver* $\Delta$ Family firm

Observations

4,568

0.829

yes

yes

R-squared

Establishment fixed effects

Workers' controls
(2)

Log Wage 2004

$0.026^{*}$

$(0.016)$

$-0.001$

$(0.020)$

Notes: (1) Dependent variable indicated in the column title. Leaver takes value 1 if the worker separated from the establishment between 1998 and 2004. Arriver takes value 1 if the worker was hired in the establishment between 1998 and 2004. Only workers aged 60 or less in 2004 who joined the DADS panel in 1998 or before are included. $\Delta F a m i l y$ firm takes value 1 if the establishment was family-owned in 2004 and not in 1998, -1 if it was family-owned in 1998 and not in 2004 and 0 otherwise. (2) Robust standard errors, clustered on firms, in parentheses. (5) Workers' controls include the following groups (except when the group is used to define the dependent variable): age ( 8 classes), tenure ( 3 classes), occupation (4 groups: manager, technician or supervisor, clerk, blue-collar), gender and a dummy variable for working full time. $(6) * * * \mathrm{p}<0.01, * * \mathrm{p}<0.05, * \mathrm{p}<0.1$.

Table 4 Changes in ownership and wage growth 1998-2004

\begin{tabular}{|c|c|c|c|c|}
\hline \multirow[b]{3}{*}{ Dependent variable } & \multicolumn{2}{|c|}{ All establishments } & \multicolumn{2}{|c|}{$\begin{array}{c}\text { Establishments that } \\
\text { changed ownership } \\
\text { between } 1998 \text { and } 2004\end{array}$} \\
\hline & (1) & (2) & (3) & (4) \\
\hline & $\Delta$ Log Wage & $\Delta$ Log Wage & $\Delta$ Log Wage & $\Delta$ Log Wage \\
\hline$\Delta$ Family Firm & $\begin{array}{c}-0.032 * * \\
(0.016)\end{array}$ & $\begin{array}{c}-0.032 * * \\
(0.016)\end{array}$ & $\begin{array}{c}-0.034 * * \\
(0.015)\end{array}$ & $\begin{array}{c}-0.034 * * \\
(0.015)\end{array}$ \\
\hline Log Relative wage 1998 & & $\begin{array}{c}-0.012 \\
(0.038)\end{array}$ & & $\begin{array}{l}-0.009 \\
(0.062)\end{array}$ \\
\hline Observations & 2,663 & 2,663 & 487 & 487 \\
\hline R-squared & 0.099 & 0.099 & 0.261 & 0.261 \\
\hline Changes in ICT and Management Pract. & yes & yes & yes & yes \\
\hline Changes in workers' controls & yes & yes & yes & yes \\
\hline Changes in establishments' controls & yes & yes & yes & yes \\
\hline
\end{tabular}

Notes: (1) Dependent variable: change in log gross hourly wage between 1998 and 2004. $\Delta$ Family firm takes value 1 if the establishment was family-owned in 2004 and not in 1998, -1 if it was family-owned in 1998 and not in 2004 and 0 otherwise. (2) Robust standard errors, clustered on firms, in parentheses. (3) Relative wage in 1998 is difference between the log wage of each individual and the average log wage of the establishment, computed in 1998. (4) Changes in ICT and Management Practices respectively denote the change in the intensity of use of information and communication technologies, and in innovative managerial practices. All regressions include two dummy variables that take the value 1 if change in ICT (resp. change in management practices) is missing (5) Changes in workers' controls include change in occupation (defined in 4 groups), change in age (defined in 8 classes), change in tenure (defined in 8 classes) and change in working full time (6) Changes in establishments' controls include change in firm size, change in the presence of union representative, change in stock market listing, all measured between 1998 and 2004. (7) *** $\mathrm{p}<0.01, * * \mathrm{p}<0.05, * \mathrm{p}<0.1$. 
Table 5 Family ownership and average separation rates 2001-2007

\begin{tabular}{|c|c|c|c|c|c|c|}
\hline Dependent variable & $\begin{array}{c}(1) \\
\text { Dismissals }\end{array}$ & $\begin{array}{c}\text { (2) } \\
\text { Quits }\end{array}$ & $\begin{array}{c}(3) \\
\text { Retirem. }\end{array}$ & $\begin{array}{c}(4) \\
\text { End-trial }\end{array}$ & $\begin{array}{c}(5) \\
\text { End-fixed } \\
\text { term }\end{array}$ & $\begin{array}{c}\text { (6) } \\
\text { All } \\
\text { separat. }\end{array}$ \\
\hline Family firm & $\begin{array}{c}-0.153 * * * \\
(0.046)\end{array}$ & $\begin{array}{c}0.055 \\
(0.079)\end{array}$ & $\begin{array}{c}0.003 \\
(0.017)\end{array}$ & $\begin{array}{c}0.024 \\
(0.030)\end{array}$ & $\begin{array}{l}-0.141 \\
(0.260)\end{array}$ & $\begin{array}{c}-0.348 \\
(0.348)\end{array}$ \\
\hline Observations & 1,295 & 1,295 & 1,295 & 1,295 & 1,295 & 1,295 \\
\hline R-squared & 0.433 & 0.528 & 0.468 & 0.506 & 0.387 & 0.462 \\
\hline establishment controls & yes & yes & yes & yes & yes & yes \\
\hline ctrl for ICT and Managt Pract & yes & yes & yes & yes & yes & yes \\
\hline workers' characteristics & yes & yes & yes & yes & yes & yes \\
\hline
\end{tabular}

Notes: (1) Dependent variable: establishment-level average of quarterly separation rates over 2001-2007, computed for each type of separation (rate of dismissals, rate of quits, etc.) as indicated in column titles. Only establishments with nonmissing observations for at least 9 quarters in 2001-2007 are included. Family firm takes value 1 if the establishment is part of a firm which is family-owned in 2004 and 0 otherwise. (2) Robust standard errors, clustered on firms, in parentheses. (3) Establishment controls include: establishment size (6 classes), age (5 classes), region, presence of union representative, being listed on the stock market and industry dummies (at 4-digits of the NACE, Rev.1, classification). (4) ICT and Management Practices are the intensity of use of information and communication technologies and of innovative managerial practices, respectively. (5) Workers' characteristics include: the proportion of women, the proportion of workers below 40 years old and the proportion of employees in 4 occupational groups (managers, technicians and supervisors, clerks, blue-collars). (6) $* * * \mathrm{p}<0.01$, ** $\mathrm{p}<0.05, * \mathrm{p}<0.1$.

Table 6 Changes in family ownership and changes in separations 1998-2004

\begin{tabular}{|c|c|c|c|c|c|c|}
\hline Dependent variable & $\begin{array}{c}(1) \\
\Delta \text { Dismiss. }\end{array}$ & $\begin{array}{c}\text { (2) } \\
\Delta \text { Quits }\end{array}$ & $\begin{array}{c}(3) \\
\Delta \text { Retirem. }\end{array}$ & $\begin{array}{c}(4) \\
\Delta \text { End- } \\
\text { trial }\end{array}$ & $\begin{array}{c}5) \\
\Delta \text { End-fixed } \\
\text { term }\end{array}$ & $\begin{array}{c}(6) \\
\Delta \text { All } \\
\text { separat. }\end{array}$ \\
\hline$\Delta$ Family Firm & $\begin{array}{c}-0.150 * * \\
(0.076)\end{array}$ & $\begin{array}{l}-0.109 \\
(0.094)\end{array}$ & $\begin{array}{c}0.052 \\
(0.047)\end{array}$ & $\begin{array}{c}-0.016 \\
(0.017)\end{array}$ & $\begin{array}{l}-0.015 \\
(0.356)\end{array}$ & $\begin{array}{l}-0.179 \\
(0.422)\end{array}$ \\
\hline Observations & 257 & 257 & 257 & 257 & 257 & 257 \\
\hline R-squared & 0.075 & 0.059 & 0.075 & 0.076 & 0.049 & 0.047 \\
\hline $\begin{array}{l}\text { Time-varying establishment } \\
\text { controls }\end{array}$ & yes & yes & yes & yes & yes & yes \\
\hline $\begin{array}{l}\text { Change in workers' } \\
\text { characteristics }\end{array}$ & yes & yes & yes & yes & yes & yes \\
\hline
\end{tabular}

Notes: (1) Dependent variable: change in the establishment-level average of quarterly separation rates over 3-years periods centred on 1998 and 2004, computed for each type of separation (rate of dismissals, rate of quits, etc.) as indicated in column titles. Only establishments with non-missing observations for at least 9 quarters in each 3-year periods are included. $\Delta$ Family firm takes value 1 if the establishment was family-owned in 2004 and not in $1998,-1$ if it was family-owned in 1998 and not in 2004 and 0 otherwise. (2) Robust standard errors, clustered on firms, in parentheses. (3) time varying establishment controls include change in firm size (defined in 6 classes), change in the presence of union representative, change in listing on the stock market, change in age (defined in 5 classes), change in the use of information and communication technologies, and change the use of innovative managerial practices, all measured between 1998 and 2004. (4) All regressions include two dummy variables that take the value 1 if change in ICT (resp. change in management practices) is missing. (5) Changes in workers' characteristics include changes in the proportion of workers by occupation (defined in 4 groups) and by gender. (6) *** $\mathrm{p}<0.01, * * \mathrm{p}<0.05, * \mathrm{p}<0.1$. 
Table 7 Sensitivity of dismissal and hiring rates to job creation and job destruction

Panel A Dismissal rates, job creation and job destruction

\begin{tabular}{|c|c|c|c|c|}
\hline Dependent variable & $\begin{array}{c}(1) \\
\text { Dismissal } \\
\text { rate }\end{array}$ & $\begin{array}{c}(2) \\
\text { Dismissal } \\
\text { rate } \\
\end{array}$ & $\begin{array}{c}(3) \\
\text { Dismissal } \\
\text { rate }\end{array}$ & $\begin{array}{c}(4) \\
\text { Dismissal } \\
\text { rate }\end{array}$ \\
\hline Job creation rate & $\begin{array}{c}0.021 * * \\
(0.010)\end{array}$ & $\begin{array}{c}0.021 * * \\
(0.011)\end{array}$ & $\begin{array}{c}0.036 * * * \\
(0.013)\end{array}$ & $\begin{array}{c}0.010^{* *} \\
(0.005)\end{array}$ \\
\hline Job destruction rate & $\begin{array}{c}0.115 * * * \\
(0.038)\end{array}$ & $\begin{array}{c}0.122 * * * \\
(0.040)\end{array}$ & $\begin{array}{c}0.161 * * * \\
(0.033)\end{array}$ & $\begin{array}{c}0.121 * * * \\
(0.010)\end{array}$ \\
\hline Job creation rate $\mathrm{x}$ Family firm & & $\begin{array}{l}-0.035^{*} \\
(0.019)\end{array}$ & $\begin{array}{c}-0.060 * * * \\
(0.022)\end{array}$ & $\begin{array}{l}-0.020^{*} \\
(0.011)\end{array}$ \\
\hline Job destruction rate $\mathrm{x}$ Family firm & & $\begin{array}{c}-0.152^{* *} * \\
(0.070)\end{array}$ & $\begin{array}{c}-0.252 * * * \\
(0.084)\end{array}$ & $\begin{array}{c}-0.078 * * \\
(0.033)\end{array}$ \\
\hline Observations & 38,360 & 38,360 & 31,236 & 31,147 \\
\hline R-squared & 0.247 & 0.286 & 0.455 & 0.723 \\
\hline establishment fixed effects & yes & yes & yes & yes \\
\hline time dummies & yes & yes & yes & yes \\
\hline $\begin{array}{l}\text { establishment controls - reduced } \mathrm{x} \\
\text { JCR/JDR. }\end{array}$ & no & no & yes & yes \\
\hline $\begin{array}{l}\text { establishment controls - extended } \mathrm{x} \\
\text { JCR/JDR. }\end{array}$ & no & no & no & yes \\
\hline workers' characteristics x JCR/JDR. & no & no & yes & yes \\
\hline
\end{tabular}

Panel B Hiring rates, job creation and job destruction

(1) (2)

(2) (3)

(4)

\begin{tabular}{lcccc} 
Dependent variable & Hiring rate & Hiring rate & Hiring rate & Hiring rate \\
\hline & & & & \\
Job creation rate & $1.019^{* * *}$ & $1.016^{* * *}$ & $1.011^{* * *}$ & $0.993^{* * *}$ \\
& $(0.018)$ & $(0.014)$ & $(0.017)$ & $(0.014)$ \\
Job destruction rate & $-0.235^{* * *}$ & $-0.223^{* * *}$ & $-0.155^{* * *}$ & $-0.236^{* * *}$ \\
& $(0.036)$ & $(0.030)$ & $(0.029)$ & $(0.020)$ \\
Job creation rate x Family firm & & -0.042 & $-0.077^{* *}$ & $-0.055^{*}$ \\
& & $(0.028)$ & $(0.032)$ & $(0.031)$ \\
Job destruction rate x Family firm & & $-0.251^{* * *}$ & $-0.170^{* *}$ & $-0.175^{* * *}$ \\
& & $(0.067)$ & $(0.082)$ & $(0.050)$ \\
& & & & \\
Observations & 38,360 & 38,360 & 31,236 & 31,147 \\
R-squared & 0.751 & 0.756 & 0.763 & 0.784 \\
establishment fixed effects & yes & yes & yes & yes \\
time dummies & yes & yes & yes & yes \\
establishment controls - reduced $x$ & no & no & yes & yes \\
JCR/JDR. & & & & \\
establishment controls - extended x & no & no & no & yes \\
JCR/JDR. & no & no & yes & yes \\
workers' characteristics x JCR/JDR. & & & & \\
\hline \hline
\end{tabular}




\section{Table 7 (cont.)}

Notes: (1) Each column presents the results of a separate regression. In Panel A, the dependent variable is the quarterly dismissal rate computed, at the establishment level, as the total number of dismissals during a quarter over the average employment level during that quarter. In Panel $\mathrm{B}$, the dependent variable is the quarterly hiring rate computed, at the establishment level, as the total number of hires during a quarter over the average employment level during that quarter. Family firm takes value 1 if the establishment is part of a firm which is family-owned in 2004 and 0 otherwise. (2) Robust standard errors, clustered on firms, in parentheses. (3) Job creation rate (JCR) and Job destruction rate (JDR) are respectively the job creation and job destruction rates in the establishment. The JCR (resp. JDR) is defined as the ratio of the net growth rate of employment between the beginning and the end of a quarter to the average employment level during that quarter, if the former is positive (resp. negative). (4) Establishment controls - reduced include: presence of union representative, being listed on the stock market, the use of information and communication technologies and the intensity of innovative managerial practices. (5) Establishment controls - extended include the previous establishment controls plus establishment size (6 classes), age (5 classes), region and industry dummies (at 2-digits of the NACE, Rev.1, classification). (6) Workers' characteristics include: the proportion of women, the proportion of workers below 40 years old and the proportion of employees in 4 occupational groups (managers, technicians and supervisors, clerks, blue-collars). (7) $* * * \mathrm{p}<0.01, * * \mathrm{p}<0.05$, $* \mathrm{p}<0.1$. 
Table 8 Family firms and perceived risk of dismissal in $\mathbf{2 0 0 4}$

(1) (2)

Dependent variable

Risk of Risk of

dismissal dismissal

Family firm

$-0.106 * * \quad-0.106 * *$

$(0.042) \quad(0.042)$

Log wage

$-0.064$

(0.063)

Observations

$3,591 \quad 3,579$

R-squared

$0.094 \quad 0.096$

workers' controls

yes yes

establishments' controls

yes yes

control for ICT and management practices

yes yes

Notes: (1) Each column presents the results of a separate regression, run at the individual worker level, where the dependent variable is the perceived risk of dismissal, evaluated on a 1-4 scale. Family firm takes value 1 if the establishment is part of a firm which is family-owned in 2004 and 0 otherwise. (2) Robust standard errors, clustered on firms, in parentheses. (3) Workers' controls include: age (8 classes), tenure (3 classes), occupation (4 groups: manager, technician or supervisor, clerk, blue-collar), gender and a dummy variable for working full time. (4) Establishment controls include: establishment size (6 classes), age (5 classes), region, presence of union representative, being listed on the stock market and industry dummies. (5) ICT and Management Practices respectively denote the intensity of use of information and communication technologies, and of innovative managerial practices. (6) *** $\mathrm{p}<0.01, * * \mathrm{p}<0.05, * \mathrm{p}<0.1$. 
Table 9 Testing for compensating wage differentials, 1998-2004

\begin{tabular}{|c|c|c|c|}
\hline Dependent variable & $\begin{array}{c}\text { All } \\
\text { Establishments } \\
\text { (1) } \\
\Delta \text { Log Wage }\end{array}$ & $\begin{array}{c}\text { Establishments that did not } \\
\text { change ownership } \\
\text { between } 1998 \text { and } 2004 \\
(2) \\
\Delta \text { Log Wage }\end{array}$ & $\begin{array}{c}\text { Establishments that } \\
\text { changed ownership } \\
\text { between } 1998 \text { and } 2004 \\
(3) \\
\Delta \text { Log Wage }\end{array}$ \\
\hline$\Delta$ Family firm & $\begin{array}{c}-0.036 * * \\
(0.017)\end{array}$ & - & $\begin{array}{l}-0.019 \\
(0.015)\end{array}$ \\
\hline$\Delta$ Dismissal rate & $\begin{array}{c}-0.005 \\
(0.010)\end{array}$ & $\begin{array}{l}-0.009 \\
(0.010)\end{array}$ & $\begin{array}{l}0.050^{*} \\
(0.026)\end{array}$ \\
\hline $\begin{array}{l}\text { Observations } \\
\text { R-squared } \\
\text { changes in ICT and Management Pract. } \\
\text { changes in workers' controls } \\
\text { changes in establishments' controls }\end{array}$ & $\begin{array}{l}2575 \\
0.103 \\
\text { yes } \\
\text { yes } \\
\text { yes }\end{array}$ & $\begin{array}{l}2095 \\
0.127 \\
\text { yes } \\
\text { yes } \\
\text { yes }\end{array}$ & $\begin{array}{l}480 \\
0.310 \\
\text { yes } \\
\text { yes } \\
\text { yes }\end{array}$ \\
\hline \multicolumn{4}{|c|}{$\begin{array}{l}\text { Notes: (1) Dependent variable: change in log gross hourly wage between } 1998 \text { and } 2004 \text {. } \Delta \text { Family firm takes value } 1 \text { if the } \\
\text { establishment was family-owned in } 2004 \text { and not in } 1998 \text {, }-1 \text { if it was family-owned in } 1998 \text { and not in } 2004 \text { and } 0 \text { otherwise. (2) } \\
\text { Robust standard errors in parentheses. (3) } \Delta \text { Dismissal rate is the change in the average quarterly dismissal rate (computed over } 3 \text {-years } \\
\text { periods centred around } 1998 \text { and 2004). (4) Changes in ICT and Management Practices respectively denote the change in the intensity } \\
\text { of use of information and communication technologies, and in innovative managerial practices. (5) All regressions include two dummy } \\
\text { variables that take the value } 1 \text { if change in ICT (resp. change in management practices) is missing. (6) Changes in workers' controls } \\
\text { include change in occupation (defined in } 4 \text { groups), change in age (defined in } 8 \text { classes), change in tenure (defined in } 8 \text { classes) and } \\
\text { change in working full time (7) Changes in establishments' controls include change in firm size, change in the presence of union } \\
\text { representative, change in listing on the stock market, all measured between } 1998 \text { and 2004. (8)*** p }<0.01, * * \text { p }<0.05, * \text { p }<0.1 \text {. }\end{array}$} \\
\hline
\end{tabular}


Appendix

\section{Descriptive Statistics and Additional Results}

Table A1 Means of variables in cross section (2004), establishment level

\begin{tabular}{|c|c|c|c|c|c|c|}
\hline \multirow[t]{2}{*}{ Variables } & \multicolumn{2}{|c|}{$\begin{array}{l}\text { Whole sample } \\
\text { (2133 obs.) }\end{array}$} & \multicolumn{2}{|c|}{$\begin{array}{l}\text { Establishments belonging to } \\
\text { family firms ( } 1087 \text { obs.) }\end{array}$} & \multicolumn{2}{|c|}{$\begin{array}{l}\text { Establishments belonging to } \\
\text { non family firms (1046 obs.) }\end{array}$} \\
\hline & Mean & Std. Dev. & Mean & Std. Dev. & Mean & Std. Dev. \\
\hline Family firms & 0.510 & 0.500 & 1.000 & 0.000 & 0.000 & 0.000 \\
\hline ICT use (standardized index) & 0 & 1 & -0.277 & 0.991 & 0.289 & 0.926 \\
\hline Management practices (standardized index) & 0 & 1 & -0.312 & 1.044 & 0.305 & 0.851 \\
\hline Establishment size (total employees) & 340.2 & 608.7 & 244.7 & 487.8 & 439.4 & 699.5 \\
\hline \multicolumn{7}{|l|}{ Establishment age: } \\
\hline less than 5 years & 0.035 & 0.185 & 0.030 & 0.169 & 0.041 & 0.199 \\
\hline 5 to 9 years & 0.072 & 0.259 & 0.068 & 0.252 & 0.076 & 0.265 \\
\hline 10 to 19 years & 0.218 & 0.413 & 0.233 & 0.423 & 0.203 & 0.402 \\
\hline 20 to 49 years & 0.425 & 0.495 & 0.448 & 0.498 & 0.402 & 0.490 \\
\hline 50 years or more & 0.249 & 0.433 & 0.220 & 0.415 & 0.279 & 0.449 \\
\hline Presence of union representative & 0.648 & 0.478 & 0.495 & 0.500 & 0.807 & 0.395 \\
\hline Listed firms or belonging to a listed group & 0.431 & 0.495 & 0.200 & 0.400 & 0.674 & 0.469 \\
\hline Productivity (in K€ per worker) & 59.49 & 50.23 & 49.75 & 29.44 & 70.43 & 64.49 \\
\hline
\end{tabular}


Table A2 Means of variables in cross section (2004), individual level

\begin{tabular}{|c|c|c|c|c|c|c|}
\hline \multirow[t]{2}{*}{ Variables } & \multicolumn{2}{|c|}{$\begin{array}{l}\text { Whole sample } \\
(511,230 \text { obs. })\end{array}$} & \multicolumn{2}{|c|}{$\begin{array}{c}\text { Establishments belonging } \\
\text { to family firms } \\
(178,989 \text { obs. })\end{array}$} & \multicolumn{2}{|c|}{$\begin{array}{c}\text { Establishments belonging } \\
\text { to non family firms } \\
(332,241 \text { obs. })\end{array}$} \\
\hline & Mean & Std. Dev. & Mean & Std. Dev. & Mean & Std. Dev. \\
\hline Gross hourly wage $(€)$ & 17.22 & 8.180 & 15.57 & 7.667 & 18.11 & 8.304 \\
\hline Female & 0.312 & 0.463 & 0.358 & 0.479 & 0.287 & 0.452 \\
\hline \multicolumn{7}{|l|}{ Occupation } \\
\hline Manager & 0.177 & 0.382 & 0.134 & 0.340 & 0.201 & 0.401 \\
\hline Supervisor or technician & 0.251 & 0.434 & 0.210 & 0.408 & 0.273 & 0.446 \\
\hline Clerk & 0.173 & 0.378 & 0.260 & 0.439 & 0.126 & 0.332 \\
\hline Blue collar & 0.399 & 0.490 & 0.398 & 0.489 & 0.400 & 0.490 \\
\hline Full time worker & 0.929 & 0.257 & 0.919 & 0.272 & 0.934 & 0.248 \\
\hline Age & 39.44 & 10.09 & 38.58 & 10.09 & 39.90 & 10.07 \\
\hline \multicolumn{7}{|l|}{ Tenure } \\
\hline Less than 1 year & 0.099 & 0.299 & 0.119 & 0.324 & 0.089 & 0.284 \\
\hline 1 to 2 years & 0.164 & 0.370 & 0.159 & 0.365 & 0.166 & 0.373 \\
\hline More than two years & 0.737 & 0.440 & 0.722 & 0.448 & 0.745 & 0.436 \\
\hline
\end{tabular}


Table A3 Means of changes in variables, 1998-2004

\begin{tabular}{lcc}
\hline Variables & Mean & Std. Dev. \\
\hline $\begin{array}{l}\text { Individual-level data } \\
\text { Change in log hourly gross wage }\end{array}$ & & \\
Change in occupation & 0.168 & 0.174 \\
$\quad$ Manager & 0.026 & 0.184 \\
$\quad$ Technicians and supervisor & 0.016 & 0.363 \\
$\quad$ Clerk & -0.004 & 0.228 \\
$\quad$ Blue-collar & -0.038 & 0.302 \\
Change in full time work & -0.030 & 0.218 \\
& & \\
Establishment-level data & & \\
Family owned 2004 - family owned 1998 & 0.017 & 0.416 \\
Change in ICT & 0.436 & 0.720 \\
Change in management practices & 0.775 & 0.810 \\
Change in being listed & 0.028 & 0.412 \\
Change in union representatives & 0.050 & 0.331 \\
Change in size & 8.372 & 133.2 \\
Change in log productivity & 0.100 & 0.355 \\
\hline
\end{tabular}

Table A4 Average of quarterly gross job and worker flows in percentage of employment, establishment level, 2001-2007

\begin{tabular}{lcccccc}
\hline Variables (in \%) & \multicolumn{2}{c}{$\begin{array}{c}\text { Whole sample } \\
(1,803 \text { obs.) }\end{array}$} & \multicolumn{2}{c}{$\begin{array}{c}\text { Establishments belonging } \\
\text { to family firms } \\
\text { (858 obs.) }\end{array}$} & \multicolumn{2}{c}{$\begin{array}{c}\text { Establishments belonging to } \\
\text { non family firms } \\
\text { (945 obs.) }\end{array}$} \\
& Mean & Std. Dev. & Mean & Std. Dev. & Mean & Std. Dev. \\
\hline Job creation rate & 1.83 & 2.79 & 2.29 & 3.53 & 1.41 & 1.78 \\
Job destruction rate & 1.81 & 3.02 & 1.93 & 3.18 & 1.70 & 2.86 \\
$\quad \begin{array}{l}\text { Hiring rate } \\
\text { Separation rate }\end{array}$ & 4.48 & 6.48 & 5.82 & 7.39 & 3.27 & 5.23 \\
$\quad$ By reason of separation: & 4.49 & 6.36 & 5.47 & 6.85 & 3.60 & 5.74 \\
$\quad$ Dismissal & & & & & & \\
$\quad$ Quit & 0.54 & 0.87 & 0.53 & 0.79 & 0.55 & 0.94 \\
$\quad$ Retirement & 1.08 & 1.77 & 1.37 & 1.99 & 0.81 & 1.50 \\
$\quad$ End of trial period & 0.18 & 0.26 & 0.16 & 0.23 & 0.19 & 0.28 \\
$\quad$ End of fixed-term contract & 0.16 & 0.80 & 0.20 & 0.85 & 0.12 & 0.75 \\
& 2.16 & 4.35 & 2.84 & 5.08 & 1.55 & 3.44 \\
\hline
\end{tabular}


Table A5 Family firms and wages in 2004 - Non-managerial workers only

\begin{tabular}{lcccc}
\hline \hline & $(1)$ & $(2)$ & $(3)$ & $(4)$ \\
Dependent variable & Log Wage & Log Wage & Log Wage & Log Wage \\
\hline Family firm & $-0.152^{* * *}$ & $-0.038^{* * *}$ & $-0.021^{* *}$ & $-0.026 * * *$ \\
& $(0.010)$ & $(0.008)$ & $(0.009)$ & $(0.008)$ \\
Observations & 420,492 & 414,827 & 348,648 & 340,160 \\
R-squared & 0.061 & 0.467 & 0.465 & 0.487 \\
Workers' controls & no & yes & yes & yes \\
Establishments' controls & no & yes & yes & yes \\
Controls for ICT and Manag. Pract. & no & no & yes & no \\
Control for log productivity & no & no & no & yes \\
\hline \hline
\end{tabular}

Notes: (1) Dependent variable: log gross hourly wage of non managers. Family firm takes value 1 if the establishment is part of a firm which is family-owned and 0 otherwise. (2) Robust standard errors, clustered on firms, in parentheses. (3) Workers' controls include: age ( 8 classes), tenure (3 classes), occupation (4 groups: manager, technician or supervisor, clerk, blue-collar), gender and a dummy variable for working full time. (4) Establishment controls include: establishment size (6 classes), age (5 classes), region, presence of union representative, being listed on the stock market and industry dummies (at 2-digits of the NACE, Rev.1, classification). (5) ICT and Management Practices are the intensity of use of information and communication technologies and of innovative managerial practices, respectively. Log productivity is the log of value added per worker. (6) $* * * \mathrm{p}<0.01, * * \mathrm{p}<0.05, * \mathrm{p}<0.1$.

Table A6 Family firms and wages - Without establishment fixed effects, 1998 and 2004.

(1)

Dependent variable

Log Wage

Family firm

$-0.027^{*}$

(0.015)

\begin{tabular}{lc} 
Observations & 8,800 \\
R-squared & 0.687 \\
Workers' controls & yes \\
Establishment controls & yes \\
Controls for ICT and Management Practices & yes \\
Time dummy & yes \\
Establishment fixed-effects & no \\
\hline
\end{tabular}

Notes: (1) Dependent variable: log gross hourly wage. Family firm takes value 1 if the establishment is part of a firm which is family-owned and 0 otherwise. (2) Robust standard errors, clustered on firms, in parentheses. (3) ICT and Management Practices are the intensity of use of information and communication technologies and of innovative managerial practices, respectively. All regressions include two dummy variables that take the value 1 if ICT (resp. management practices) is missing. (4) Workers' controls include: age (8 classes), tenure (8 classes), occupation (4 groups: manager, technician or supervisor, clerk, blue-collar), gender and a dummy variable for working full time. (5) Establishment controls include: establishment size (6 classes), age (5 classes), region, presence of union representative, being listed on the stock market and industry dummies corresponding to the 2digit NACE (Rev.1) classification. (6) *** $\mathrm{p}<0.01$, ** $\mathrm{p}<0.05, * \mathrm{p}<0.1$. 
Table A7: Change in family ownership and firm pre-change characteristics - Point estimates and standard errors on $\Delta$ Family firm

\begin{tabular}{lcccccc}
\hline \hline & $(1)$ & $(2)$ & $(3)$ & $(4)$ & $(5)$ & $(6)$ \\
Dependent variable & ROE & ROCE & $\begin{array}{c}\text { Log } \\
\text { Productivity }\end{array}$ & $\begin{array}{c}\text { Log Size } \\
\text { Log } \\
\text { Wage }\end{array}$ & $\begin{array}{c}\text { Log Firm } \\
\text { Age }\end{array}$ \\
\hline \multirow{2}{*}{ 1998 Level } & 0.003 & -0.022 & -0.007 & 0.082 & 0.008 & 0.073 \\
\multirow{2}{*}{ 1994-1998 Change } & $(0.031)$ & $(0.024)$ & $(0.048)$ & $(0.164)$ & $(0.028)$ & $(0.129)$ \\
& 0.055 & -0.005 & 0.025 & 0.048 & 0.017 & - \\
& $(0.125)$ & $(0.026)$ & $(0.036)$ & $(0.131)$ & $(0.022)$ & -
\end{tabular}

Notes: (1) Each cell corresponds to a different regression where the dependent variable is indicated in the column titles (in level or changes as specified in line headings). Each cell shows point estimates and standard errors of the $\Delta F a m i l y$ firm variable where $\Delta$ Family firm takes value 1 if the establishment was family-owned in 2004 and not in $1998,-1$ if it was family-owned in 1998 and not in 2004 and 0 otherwise. (2) Robust standard errors, clustered on firms, in parentheses. (3) ROE (Return On Equity) is the percentage ratio of net profits to equity, ROCE (Return on Capital Employed) is the percentage ratio of earnings before interest and taxes (EBIT) to capital employed, log Productivity is the log of value added per worker, log Size is the log of the number of employees, log Wage is the log of the gross annual wage and log Firm Age is the log of firm age; all these variables are defined at the firm level. (4) All equations with a dependent variable in levels include the following establishment-level controls - intensity in ICT and management practices, region, presence of union representative, being family-owned, being listed on the stock market and industry dummies corresponding to the 2-digit NACE (Rev.1) classification. No control is included in equations with a dependent variable in changes. (5) $* * * \mathrm{p}<0.01, * * \mathrm{p}<0.05, * \mathrm{p}<0.1$.

Table A8. Change in family ownership and characteristics of leavers and stayers.

(1) (2) $\Delta$ Log Wage $\Delta$ Log Wage 1994-1998 2004-2006
(3)

Log Age Female
(5) Manager
$\&$ Tech.

(6) (7) $\log$ Tenure

\begin{tabular}{lccccccc}
\hline & & & & & & \\
Leaver & 0.011 & $0.029 * *$ & $-0.078 * * *$ & 0.001 & $0.049 * *$ & 0.013 & $-0.513 * * *$ \\
Leaver*AFamily & $(0.012)$ & $(0.012)$ & $(0.011)$ & $(0.017)$ & $(0.022)$ & $(0.008)$ & $(0.053)$ \\
firm & -0.011 & -0.017 & -0.007 & -0.054 & -0.044 & 0.013 & -0.036 \\
& $(0.025)$ & $(0.017)$ & $(0.027)$ & $(0.042)$ & $(0.048)$ & $(0.012)$ & $(0.140)$ \\
Observations & 2,477 & 2,575 & 4,568 & 4,568 & 4,568 & 4,568 & 4,188 \\
R-squared & 0.566 & 0.477 & 0.450 & 0.564 & 0.494 & 0.539 & 0.598 \\
Estab. fixed effects & yes & yes & yes & yes & yes & yes & yes \\
Workers' controls & yes & yes & yes & yes & yes & yes & yes \\
\hline
\end{tabular}

Notes: (1) Dependent variable indicated in the column title. Unless otherwise specified, year is 1998. In Columns 4, 5 and 6 the dependent variable is dichotomous. Leaver takes value 1 if the worker separated from the establishment between 1998 and 2004. Only workers aged 60 or less in 2004 who joined the panel DADS in 1998 or before are included. $\Delta$ Family firm takes value 1 if the establishment was family-owned in 2004 and not in $1998,-1$ if it was family-owned in 1998 and not in 2004 and 0 otherwise. (2) Robust standard errors, clustered on firms, in parentheses. (3) In Column 1 only those that were in the same establishment in both 1994 and 1998 are included. In Column 2 those staying with the same establishment between 1998 and 2004 but leaving it between 2004 and 2006 are excluded. (4) In Column 2 establishment fixed effects refer to establishments in 1998. (5) Workers' controls include the following groups (except when the group is used to define the dependent variable): age ( 8 classes), tenure ( 3 classes), occupation (4 groups: manager, technician or supervisor, clerk, blue-collar), gender and a dummy variable for working full time. When Log Age is the dependent variable, log Tenure is not included and vice versa. Changes in workers' controls over 1994-1998 and 2004-2008 are included in Columns 1 and 2, respectively. (6) *** p<0.01, ** p<0.05, * p<0.1. 
$\Delta$ Family Firm

Observations

R-squared

changes in ICT and Management Pract.

changes in workers' controls

changes in establishments' controls
$-0.046 * *$

(0.018)

$-0.034 *$

(0.017)

\section{2,017}

0.151

$\begin{array}{ll}\text { yes } & \text { yes } \\ \text { yes } & \text { yes } \\ \text { yes } & \text { yes }\end{array}$

Notes: (1) Individuals in the top and bottom decile of the distribution of relative wages in 1998 are excluded from the sample. (2) Dependent variable: change in log gross hourly wage between 1998 and 2004. $\Delta$ Family firm takes value 1 if the establishment was family-owned in 2004 and not in 1998, -1 if it was family-owned in 1998 and not in 2004 and 0 otherwise. (3) Robust standard errors, clustered on firms, in parentheses. (4) Changes in ICT and Management Practices respectively denote the change in the intensity of use of information and communication technologies, and in innovative managerial practices. All regressions include two dummy variables that take the value 1 if change in ICT (resp. change in management practices) is missing (5) Changes in workers' controls include change in occupation (defined in 4 groups), change in age (defined in 8 classes), change in tenure (defined in 8 classes) and change in working full time (6) Changes in establishments' controls include change in firm size, change in the presence of union representative, change in stock market listing, all measured between 1998 and 2004. (7) $* * * p<0.01, * * p<0.05, * p<0.1$.

Table A10: Family firms and dismissals: 2001-2007 with control for permanent workers and 2003-2005
(1)

Dismissal rate 2001-2007
(2)

Dismissal rate 2003-2005
$-0.136 * * *$
$(0.046)$
$0.003 * * *$
$(0.001)$
Family firm

1,280

0.431

1,090

Observations

yes

yes

0.397

establishment controls

controls for ICT and Management Practices

workers' characteristics yes

Notes: (1) Dependent variable: establishment-level average of quarterly dismissal rates over the periods indicated in column titles. Only establishments with non-missing observations for at least 9 quarters are included. Family firm takes value 1 if the establishment is part of a firm which is family-owned in 2004 and 0 otherwise. (2) Robust standard errors, clustered on firms, in parentheses. (3) Establishment controls include: establishment size (6 classes), age (5 classes), region, presence of union representative, being listed on the stock market and industry dummies corresponding to the 4digit NACE (Rev.1) classification. (4) ICT and Management Practices are the intensity of use of information and communication technologies and of innovative managerial practices, respectively. (5) Workers' characteristics include: the proportion of women, the proportion of workers below 40 years old and the proportion of employees in 4 occupational groups (managers, technicians and supervisors, clerks, blue-collars). (6) $* * * \mathrm{p}<0.01, * * \mathrm{p}<0.05, * \mathrm{p}<0.1$. 


\section{Sample Definition}

\section{Data Appendix}

The REPONSE dataset covers 2,930 establishments in 2004. We keep only firms being either family owned or for which ownership is dispersed, private-equity or joint-ventures, thereby dropping all associations, charities and governmental organisations operating in the business sector as well as firms owned by their own workers, by the government or by other types of shareholders (e.g. mutual companies). This brings down our sample to 2,133 establishments. For 481 of these establishments we have data on family ownership in 1998 by using the panel subsample of the REPONSE survey.

\subsection{Wage equations}

We matched our selection of REPONSE establishments with Social Security records (the DADS dataset). These contain information on gross hourly wages (constructed as gross annual wages divided by the number of hours worked), gender, age, occupation, working full time or part time, and a rough measure of job tenure for nearly all workers in the French private sector. We remove from the DADS dataset CEOs and top executives as well as small jobs, farmers, apprentices, workers under a subsidized contract, employees working at home and employees working less than one month in the year. We also exclude employees working on average less than 6 or more than 10 hours per day or aged less than 21 or more than 59 years. We also drop the lowest and highest percentiles of the hourly wage distribution of the remaining workers and we exclude establishments for which we do not have at least 5 valid observations ( 17 establishments). These operations are aimed at selecting core workers for whom we have a good measure of the hourly wage. Our final sample contains 511,230 employees working, in 2004, in 1,995 establishments (1,748 firms) being either family owned or having a dispersed ownership.

The REPONSE survey was designed to have a panel subsample. The establishments belonging to this subsample were surveyed both in 1998 and in 2004. The panel subsample of the REPONSE survey was matched with the DADS panel on which we performed the same data cleaning as described in the previous paragraph for the cross-section dataset (except for the condition on the number of valid observations per establishment, that is obviously not applied in the case of the DADS panel). We exclude all establishments for which we do not have at least one valid observation in both 1998 and 2004. After these operations, we are left with 4,713 workers in 1998 and 5,424 workers in 2004 from 417 establishments (410 firms).

\subsection{Job security equations}

We matched our selection of REPONSE establishments with the DMMO-EMMO dataset, which contains quarterly data on job and worker flows. Even if filling the DMMO-EMMO questionnaire is compulsory for all establishments with 50 or more employees and one fourth of the establishments with 10 to 49 employees, declarations are often incomplete. As a consequence, for our main sample (2001-2007) and once associations, charities and governmental organisations operating in the business sector as well as firms owned by their own workers, by the government or by other types of shareholders are excluded, the match results in 1,803 establishments that are linked at least once. Similarly, for the panel sample, we matched the panel subsamples of REPONSE 1998 and REPONSE 2004 with, respectively, the 1997-1999 and 2003-2005 waves of the DMMO-EMMO, resulting in 374 establishments that are linked at least once in each subperiod. The DMMO-EMMO database is composed of two datasets, one containing quarterly variables at the establishment level, including net employment growth and total number of movements (hirings plus separations), and another one containing information for each movement (that is, for each hiring or separation event). 13 establishment-by-quarter observations, for which the total number of movements in the two datasets were inconsistent, were also omitted from the sample.

The REPONSE survey contains individual information for a subsample of employees, randomly drawn out of the group of workers with more than 15 months of tenure. For the subjective job security 
equations, we use a subsample of 4,599 workers in 1,856 establishments, for which data on perceived risk of dismissal and on ownership are available. As always, associations, charities and governmental organisations operating in the business sector as well as firms owned by their own workers, by the government or by other types of shareholders are excluded from this sample.

\section{Main variables}

\subsection{Establishment- or firm-level variables}

Family ownership: managers are asked: "What is the type of the main category of shareholder of the firm?" Possible answers are family/individual/French or foreign financial company/ French or foreign non-financial company/the State/the workers/others. We define a dummy variable for family ownership which takes value 1 if the main category of shareholder is either a family or an individual and 0 otherwise. Source: REPONSE.

ICT use: managers are asked what proportion of the employees use computers, the Internet or the Intranet. For each of these new technologies, the answer is coded from 0 to 4 with 0 corresponding to "nobody", 1 to "less than 5\%", 2 to "5-19\%", 3 to "20 to 49\%" and 4 to "50\% and more". Our ICT variable is defined as the sum of the answers over the three types of technologies. It thus captures the intensity of use of ICT at the establishment level and varies between 0 and 12 . We standardise it to 0 mean and 1 standard deviation. Source: REPONSE.

Innovative managerial practices: our index of innovative managerial practices is the weighted sum of the following 8 composite variables, most of which are directly inspired by Bloom and Van Reenen (2007):

Performance dialogue. Composite variable scoring from 0 to 12. Sum of the 4 items below:

- Share of employees involved in quality circles: nobody $=0$, less than $5 \%=1$, from 5 to $19 \%=2$, from 20 to $49 \%=3,50 \%$ and more $=4$

- Share of employees involved in shopfloor meetings: nobody $=0$, less than $5 \%=1$, from 5 to $19 \%=2$, from 20 to $49 \%=3,50 \%$ and more $=4$

- Share of employees involved in expression groups: nobody $=0$, less than $5 \%=1$, from 5 to $19 \%=2$, from 20 to $49 \%=3,50 \%$ and more $=4$

Workers' participation. Composite variable scoring from 0 to 7 . Sum of the 7 items below:

- $\quad$ firm project: no $=0$, yes $=1$

- $\quad$ seminars: no $=0$, yes $=1$

- firm newspaper: no $=0$, yes $=1$

- $\quad$ open day: no $=0$, yes $=1$

- $\quad$ suggestion box: no $=0$, yes $=1$

- $\quad$ satisfaction survey: no $=0$, yes $=1$

- $\quad$ quality action: no $=0$, yes $=1$

Workers' autonomy. Composite variable scoring from 0 to 2. Sum of the 2 items below:

- In the event of incidents, workers are encouraged to refer to a supervisor $=0$, to solve the problem themselves $=1$

- $\quad$ work is defined : in terms of precise content $=0$, in terms of goal to reach $=1$

Existence of targets. Composite variable scoring from 0 to 6. Sum of the 6 items below:

Existence of quantitative targets in terms of:

- financial return: no $=0$, yes $=1$

- $\quad$ budget balance: no $=0$, yes $=1$

- labour cost: no $=0$, yes $=1$

- quality: no $=0$, yes $=1$

- $\quad$ growth: no $=0$, yes $=1$

- $\quad$ security: no $=0$, yes $=1$ 
Managing human capital. Dummy variable that takes value 1 if there exists a training scheme, 0 otherwise

Rewarding high performance for managers. Composite variable scoring from 0 to 3 . Sum the 3 items below:

- $\quad$ Existence of a bonus (premium) based on individual performance: no $=0$, yes $=1$

- $\quad$ Existence of a bonus (premium) based on collective performance: no $=0$, yes $=1$

- $\quad$ Existence of stock options schemes: no $=0$, yes $=1$

Rewarding high performance for non-managers. Composite variable scoring from 0 to 3 . Same components and scoring as for managers.

Performance review. Composite variable scoring from 0 to 4 . Sum of the 2 items below:

- Individual assessment for managers : no $=0$, for some of them $=1$, for all $=2$

- Individual assessment for non-managers : no $=0$, for some of them $=1$, for all $=2$

Consequence management. Composite variable scoring from 0 to 4 . Sum of the 2 items below:

- Impact of individual assessment on wages: no assessment or no impact $=0$, indirect or long term impact $=1$, direct impact $=2$

- Impact of individual assessment on promotions: no assessment or no impact $=0$, indirect or long term impact $=1$, direct impact $=2$

Our summary index of innovative managerial practices is the sum of the above composite variables, each variable being weighted by the inverse of its maximum score. The raw summary index ranges between 0 and 8.4 (with mean 5.3), and is standardised to 0 mean and 1 standard deviation. Source: REPONSE.

Establishment size: number of employees in the establishment. Computed at the end of the year and grouped into 6 categories: less than 50 workers, 50-99 workers, 100-199, 200-499, 500-999 and 1000 workers and above. Source: DADS, when available, and REPONSE otherwise.

Establishment age: grouped into 5 categories: less than 5 years, 5 to 9 years, 10 to 19 years, 20 to 49 years and 50 years or more. Source: REPONSE.

Presence of union representative: dummy variable equal to 1 if there is at least 1 union representative in the establishment. Source: REPONSE.

Percentage of permanent workers: proportion of workers on open-ended contracts. Source: REPONSE.

Regions: 10 macro-regions in which the establishment is located, resulting from aggregation of French administrative regions. We create a dummy variable for each of them. Source: REPONSE.

Industries: detailed NAF codes are available in REPONSE. Using a standard map we aggregate them at the 2-digit level of the NACE rev. 1 classification.

Listed on the stock market: we build a dummy variable equals to 1 if the establishment is part of a firm listed on the stock market or belonging to a listed group. Source: REPONSE.

Productivity: annual value-added per employee in $\mathrm{K} €$, measured at the firm level. Source: DIANE.

Return On Equity (ROE): percentage ratio of net profits to equity, measured at the firm level. For each year, we exclude top and bottom percentiles. Source: DIANE.

Return On Capital Employed (ROCE): percentage ratio of company earnings before interest and taxes (EBIT) to capital employed, measured at the firm level. For each year, we exclude top and bottom percentiles. Source: DIANE. 
Firm size: Number of employees in the firm. Source: DIANE.

Average annual wages: ratio of the firm's gross wage bill to total number of employees, measured at the firm level. Source: DIANE.

Firm age: difference between the current year and the year of incorporation. Source: DIANE.

Job creation rate: ratio of the net growth of employment between the beginning and the end of a quarter to the average employment level during that quarter, if the former is positive, and 0 otherwise. The average employment level during a quarter is computed as half of the sum of the employment levels at the beginning and the end of the quarter. Source: DMMO-EMMO.

Job destruction rate: ratio of the absolute value of net growth of employment between the beginning and the end of a quarter to the average employment level during that quarter, if the former is negative, and 0 otherwise. The average employment level during a quarter is computed as half of the sum of the employment levels at the beginning and the end of the quarter. Source: DMMO-EMMO.

Separation rate: for each type of separation, ratio of all movements during a quarter - excluding those corresponding to job spells shorter than one month and transfers across establishments of the same firm - to the average employment level during that quarter (see above). Correspondingly, the total separation rate is the ratio of all separations - whatever their type - during a quarter to the average employment level during that quarter. Source: DMMO-EMMO.

Hiring rate: ratio of all hires during a quarter to the average employment level of that quarter (see above). This ratio is obtained from the sum of separation and net employment growth rates, exploiting the identity for which net employment growth must be equal to hirings minus separations. Source: DMMO-EMMO.

\subsection{Individual-level variables}

All variables come from DADS except when elsewhere specified.

Gross hourly wages include basic wages, and performance and non-performance related premiums and bonuses. They are net of employers and workers' social contributions but gross of income taxes.

Risk of dismissal: Workers are asked: "In the next 12 months, do you feel that the risk that you lose your job is: very high/high/low/zero?" We build a variable equal to 1 if the perceived risk is zero, 2 if it is low, 3 if it is high and 4 if it is very high. Source: REPONSE.

Occupations are grouped into 4 groups: managers, supervisors and technicians, clerks, blue-collars.

Full time worker: dummy variable taking value 1 if the worker works full time, 0 otherwise.

Age is grouped into 8 categories: 21 to 25 years, 26 to 30 years, 31 to 35 years, 36 to 40 years, 41 to 45 years, 46 to 50 years, 51 to 55 years, 56 to 60 years. Workers aged 20 years or less or more than 60 years are excluded from our sample.

Job tenure is grouped into 3 categories in cross-section equations: 1 year or less, more than 1 to 2 years, more than 2 years. More information is available in the DADS panel. In this case job tenure is grouped into 8 categories: 1 year or less, 1 to 2 years, 2 to 4 years, 4 to 7 years, 7 to 10 years, 10 to 15 years, 15 to 20 years, more than 20 years. 